\title{
Iconografia tropical: motivos locais na arte colonial brasileira'
}

\section{Eduardo Luis Araújo de Oliveira Batista ${ }^{2}$}

RESUMO: Este artigo estuda a representação visual da natureza tropical na arte sacra do período colonial brasileiro, entre os séculos XVI e XVIII, época em que as artes visuais do país se desenvolveram no contexto do barroco introduzido pelos missionários católicos. Foi na decoração das igrejas que apareceram algumas das primeiras representações artísticas de elementos da natureza local, notadamente as frutas tropicais, produzindo novas combinações junto à tradicional ornamentação fitomórfica europeia, constituída de folhas de acantos e vinhas. Após um levantamento das ocorrências dessas manifestações da temática local na decoração dos templos presentes nas regiões nordeste e sudeste do país, este trabalho aborda, nos textos dos viajantes e missionários produzidos no período, as interpretações cristãs da natureza tropical que permitiram o aproveitamento desses motivos como parte da estratégia de pregação e conversão católica por meio da alegorização moral e religiosa da natureza do Novo Mundo.

PALAVRAS-CHAVE: Barroco. Frutas Tropicais. Iconografia.

ABSTRACT: This paper studies the visual representation of local nature in the sacred art developed during the colonial period of Brazilian history. In this period, between the XVIth and the $\mathrm{XVIllth}$ centuries, the visual arts in the country evolved in the context of the Baroque introduced by Catholic missionaries. It was in the decoration of the churches in which the first representations of aspects of local nature, mostly the tropical fruits, appeared in Brazilian visual arts, producing new combinations together with the traditional European phytomorphic ornamentation of acanthus leaves and grapes. This research draws upon texts written by travellers and missionaries during the period to demonstrate how the Europeans interpreted and represented tropical nature and used these representations as part of the Catholic preaching strategy by means of moral and religious allegorization of the New World nature.

KEYWORDS: Baroque. Iconography. Tropical Fruits.

\begin{abstract}
1. Pesquisa desenvolvida com bolsa de pós-doutorado Fapesp na ECA-USP entre 2012 e 2015.

2. Pesquisador de pós-doutorado no Programa de Pós-Graduação em Letras, Universidade Federal do Espírito Santo. E-mail: <eduardolaob@yahoo. com.br>.
\end{abstract}


Introdução

Foi por meio da ação dos missionários católicos que o Barroco europeu foi introduzido no território brasileiro e prevaleceu nas artes locais durante praticamente todo o período colonial, entre os séculos XVI e XVIII, concentrando, ao redor da Igreja Católica, a maior parte da produção artística visual da colônia. Apesar de importado, o Barroco adquiriu características próprias na produção da colônia ao longo do tempo, culminando no Barroco Mineiro, considerado umas das manifestações iniciais de uma arte original brasileira. No entanto, fora do âmbito do Barroco Mineiro, as artes sacras coloniais manifestaram outros sinais de originalidade, um dos quais se baseou na representação de uma temática local junto à tradicional iconografia religiosa barroca desenvolvida na Europa. Entre esses temas locais incorporados à iconografia e ornamentação sacra, encontram-se representações de figuras étnicas como indígenas e mulatos, de fauna nativa e, em maior escala, de frutas tropicais, que passaram a figurar junto às tradicionais videiras, peras e folhas de acanto na decoração das igrejas. Neste trabalho, apresentamos um levantamento das ocorrências de representações de frutas tropicais na decoração dos templos barrocos do período colonial e oferecemos uma interpretação para sua presença e simbolismo. Enquanto alguns autores veem nesse fenômeno um processo de resistência ou afirmação da identidade nativa, propomos uma diferente perspectiva. Segundo nosso ponto de vista, além do apelo plástico das exóticas frutas tropicais, atribuímos seu aproveitamento iconográfico na arte colonial brasileira à existência de uma tradição europeia prévia no uso de frutas como ornamentos, a qual foi adaptada à realidade local. Esse aproveitamento teria sido respaldado pelo simbolismo religioso que as frutas adquiriram por meio da interpretação cristã da natureza do Novo Mundo desenvolvida pelos missionários e viajantes cristãos portugueses. Também responderia muito mais a uma visão exótica do colonizador europeu sobre a natureza brasileira do que a uma afirmação da presença nativa nas artes coloniais.

movimento de absorção das imagens das frutas tropicais nas artes visuais do período colonial brasileiro é precedido e respaldado pela representação e interpretação encontrada nos textos dos viajantes e missionários europeus que descreveram de forma pioneira as maravilhas da natureza tropical. Nesses textos, podemos entrever as primeiras interpretações religiosas e cristãs da natureza brasileira, que são encontradas em textos literários, relatos de viagem e tratados religiosos. De um primeiro encantamento e surpresa com o exotismo e diversidade da fauna e flora local, os autores passam a oferecer interpretações alegóricas cristãs que são concomitantes à representação visual na arte barroca, como veremos.

Nas obras épicas do começo do século XVIII, que inauguram o que Sérgio Buarque de Holanda chama de tradição descritiva e topográfica, encontramos peças que descrevem e elogiam a natureza brasileira, destacando as suas frutas. Como afirma Holanda, em seus Capítulos de literatura colonial, "com 
a 'silva' onde são relacionadas as maravilhas agrestes de sua decantada ilha da Maré, Botelho de Oliveira tinha inaugurado no Brasil a fórmula topográfica e descritiva, tão explorada mais tarde por nossos poetas épicos [...]". ${ }^{3}$ Holanda refere-se ao trecho do épico Música do Parnaso, de 1705, no qual o autor interrompe sua longa narrativa sobre os feitos de D. Nuno Álvares Pereira de Melo para descrever sua terra natal, a ilha da Maré, localizada na Baía de Todos os Santos. Nesse trecho, as produções naturais da terra, dos frutos do mar às frutas tropicais, são elogiadas numa lista infindável da qual citamos alguns versos:
As fruitas se produzem copiosas,
E são tão deleitosas,
Que como junto ao mar o sítio é posto,
Lhes dá salgado o mar o sal do gosto. [...]
As pitangas fecundas
São na cor rubicundas,
E no gosto picante comparadas
São de América ginjas disfarçadas:
As pitombas douradas, se as desejas,
São no gosto melhor do que as cerejas,
E para terem o primor inteiro
A vantagem thes levam pelo cheiro.
[...] As bananas no Mundo conhecidas
Por fruto, e mantimento apetecidas,
Que o céu para regalo, e passatempo
Liberal as concede em todo o tempo. ${ }^{4}$

Não só as frutas locais são apresentadas, mas a fertilidade da terra também acolhe as frutas e produtos de outras origens:

As laranjas da terra

Pouco azedas são, antes se encerra

Tal doce nestes pomos,

Que o tem clarificado nos seus gomos;

Mas as de Portugal entre alamedas

São primas dos limões, todas azedas.

Nas que chamam da China

Grande sabor se afina,

Mais que as da Europa doces, e melhores,

E têm sempre a vantagem de maiores,

E nesta maioria,

Como maiores são, têm mais valia.

$[\ldots]$ 
5. Oliveira (2013, p. 2).

6. Holanda (1991, p. 54).
As fruitas quase todas nomeadas

São ao Brasil de Europa trasladadas,

Porque tenha o Brasil por mais façanhas

Além das próprias fruitas, as estranhas. [... $]^{5}$

A enumeração das belezas naturais foi uma das práticas adotadas na literatura pela fórmula topográfica e descritiva. Essa enumeração é caracterizada por Holanda como "o modo de exprimir o mundo natural que consiste em fragmentálo numa sequência de elementos destacados, para em seguida recompô-los numa

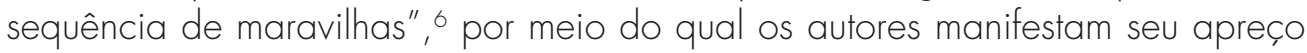
pelo rincão familiar. Esse mesmo impulso de nativismo, ou de amor à terra natal, teria motivado a obra de outro escritor do século XVIII, Frei Manuel de Santa Maria Itaparica, que, em seu épico religioso Eustáquidos, de 1769, no trecho Descrição da llha de Itaparica, rende homenagem às belezas do local onde nasceu, desenvolvendo a mesma fórmula descritiva da enumeração, como podemos ver nestes versos destacados:

XLVII

As frutas se produzem copiosas,

De várias castas e de várias cores,

Umas se estimam muito por cheirosas,

Outras levam vantagem nos sabores:

São tão belas, tão lindas e formosas,

Que estão causando à vista mil amores,

E se nos prados Flora mais blasona,

São os pomares glória de Pomona.

LVI

Inumeráveis são os cajus belos,

Que estão dando prazer por rubicundos,

Na cor também há muitos amarelos,

E uns e outros ao gosto são jucundos;

E só bastava para apetecê-los

Serem além de doces tão fecundos,

Que em si têm a Brasílica castanha

Mais saborosa que a que cria Espanha.

LVII

Os araçás diversos e silvestres,

Uns são pequenos, outros são maiores:

Oitis, cajás, pitangas, por agrestes,

Estimadas não são dos moradores:

Aos mar'cujás chamar quero celestes, 
Porque contêm no gosto tais primores, instaurou uma tradição que se fortaleceu com os épicos $\bigcirc$ Uraguai (1769), de José Basílio da Gama, e Caramuru (1781), de Frei José de Santa Rita Durão. Holanda atribui a Frei Itaparica:

Ter ele sabido escolher e fixar em grande parte a tópica do sentimento nacional nascente, que, a partir de seu livro, se incorpora à nossa tradição épica [...]. Um dos elementos dessa tópica é o já lembrado elenco de belezas e riquezas do rincão familiar, herança de Botelho de Oliveira que, incluído agora num quadro épico, será retomado pelos sucessores, a começar por Santa Rita Durão. ${ }^{8}$

Nos poemas citados, a imagem de fartura e abundância que a enumeração quase caótica de produtos naturais da terra oferece alimenta o caráter nativista dessas produções, que não deve ser confundido com algum tipo de inspiração nacionalista nesse momento. A imagem de fartura e fertilidade da terra, que já havia sido lançada pioneiramente por Pero Vaz de Caminha em sua famosa carta do descobrimento, na qual afirmara que "águas são muitas; infindas. E em tal maneira é graciosa que, querendo-a aproveitar, dar-se-á nela tudo, por bem das águas que tem", 9 é aqui evocada na diversidade e na originalidade dos produtos locais e estrangeiros. Essa mesma imagem de abundância e fartura simbolizada pelos frutos tropicais inspirou o artista Albert Eckhout a pintar suas naturezas-mortas durante o período que integrou a comitiva artística e científica trazida por Maurício de Nassau em seu governo (entre 1637 e 1644) das regiões da então colônia portuguesa ocupadas pelos holandeses no século XVII. Assim como nos épicos acima citados, Eckhout representou as nativas frutas tropicais junto a exemplares europeus e de outros continentes, conjugando a imagem do exotismo com a de fartura e fertilidade da terra que gera produtos melhores do que os colhidos em suas terras de origem.

Além da imagem de abundância e exotismo, presentes nos épicos do século XVIII e nas pinturas do holandês Eckhout, as frutas tropicais também ofereciam a possibilidade de serem interpretadas segundo uma visão religiosa cristã. $\bigcirc$ maior exemplo dessa apropriação pelo discurso católico dos elementos da natureza brasileira encontra-se no livro Frutas do Brasil, de Frei Antônio do Rosário, publicado em Lisboa em 1702 (Figuras 1 e 2). Apesar do título, o livro não é um trabalho de botânica ou de história natural, mas uma obra religiosa na qual o autor apresenta um conjunto de parábolas de cunho moral e cristão, utilizando-se das frutas brasileiras como objetos de suas alegorias. Segundo Berty Biron, "trata-se de um discurso alegórico com o fim de difundir a fé católica no Novo Mundo". 10 Em seu livro, Frei Rosário, capuchinho nascido em Lisboa que viveu no Brasil entre 1686 e 1704, 
11. Biron (2009, p. 51, 53).

12. Holanda (2000).

13. Sousa (1938, p. 223). descreve 36 frutas tipicamente nativas do Brasil, entre as quais o abacaxi, o mamão, a jabuticaba, o caju, a mangaba, a pitanga, e o maracujá - "cujos predicados devem ser imitados ou evitados, conforme a situação. [...]por meio das sedutoras imagens das exóticas frutas brasileiras, Frei Antônio do Rosário propõe-se a ensinar e propagar a essência da filosofia cristã, com seus preceitos morais, numa linguagem impregnada da religiosidade vigente na época". " Frei Rosário estabeleceu um exercício retórico barroco ao encontrar relações entre as características das 36 frutas brasileiras por ele elencadas e as mensagens morais e religiosas cristãs. De todas as frutas citadas, porém, duas se destacaram no imaginário colonial religioso sobre a natureza brasileira, o abacaxi e o maracujá, este representado por sua flor.

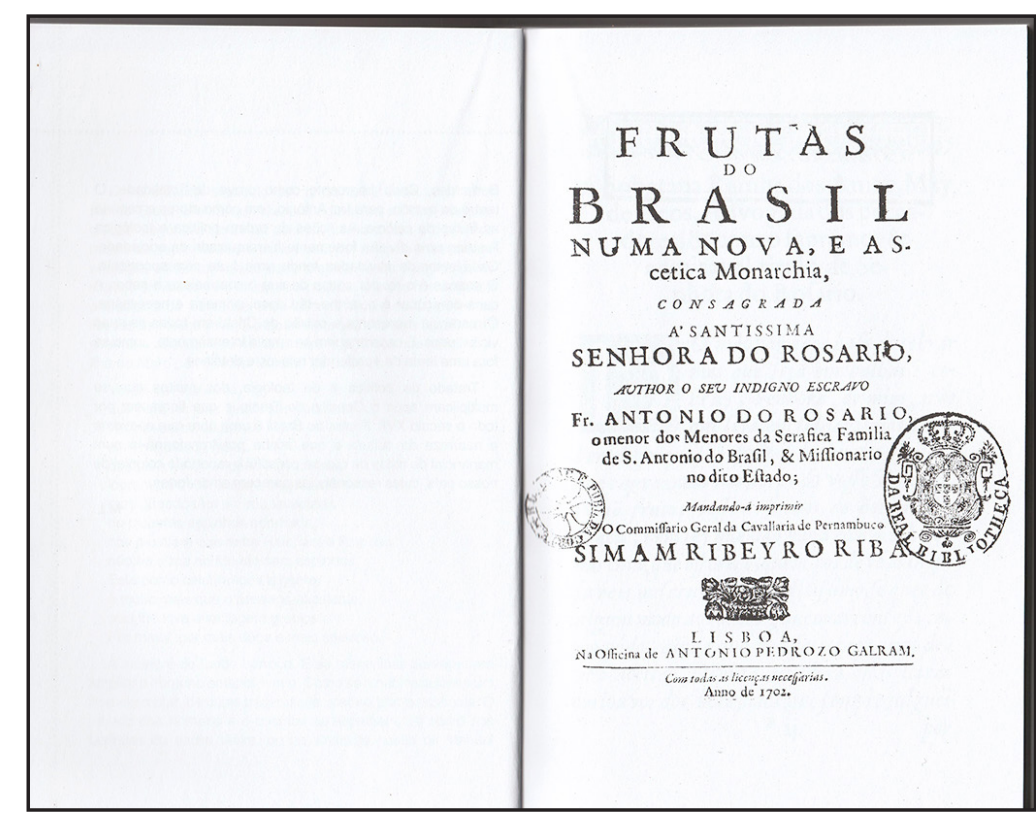

Figuras 1 e 2 - Folha de rosto e sumário de Frutas do Brasil, de Frei Antônio do Rosário (1702)

Sérgio Buarque de Holanda traça as primeiras menções brasileiras à flor de maracujá, ou flor da paixão, ao cronista português Gabriel Soares de Sousa, em seu Tratado descritivo do Brasil, de 1587 (publicado somente em 1851). ${ }^{12}$ Nesse momento, ainda despida de sua conotação religiosa, a flor é descrita como "uma flor branca muito formosa e grande que cheira muito bem, donde nascem umas frutas como laranjas pequenas, muito lisas por fora; a casca é da grossura da das laranjas de cor verde-clara, e tudo o que tem dentro se come, que além de ter bom cheiro tem suave sabor". ${ }^{13}$ Após ser citada por Antonil ou Ambrósio Fernandes Brandão nos Diálogos das grandezas do Brasil (16181, também apenas por sua beleza, a flor passa a ser notada pelas analogias que suas características sugerem com a paixão de Cristo na obra História do Brasil, do franciscano brasileiro Frei Vicente de Salvador, concluída em 1627, mas publicada apenas em 1888. Frei Vicente a descreve: 
Maracujá é outra planta que trepa pelos mattos e também a cultivam e põem em latadas nos pateos e quintais; dão frutos de quatro ou cinco sortes, uns maiores, outros menores, uns amarellos, outros roxos, todos mui cheirosos e gostosos. E o que mais se pode notar é a flor, porque além de ser formosa e de várias côres, é mysteriosa: começa no mais alto em três folhinhas, que se rematam em um globo que representa as três divinas pessoas em uma divindade, ou (como outros querem) os três cravos com que Christo foi encravado, e logo têm abaixo do globo (que é o fruto) outras cinco folhas, que se rematam em uma roxa corôa, representando as cinco chagas e corôa de espinhos de Christo Nosso Redemptor. ${ }^{14}$
14. Salvador (1918, p. 32).

15. Holanda (2000, p. 283).

Figura 2

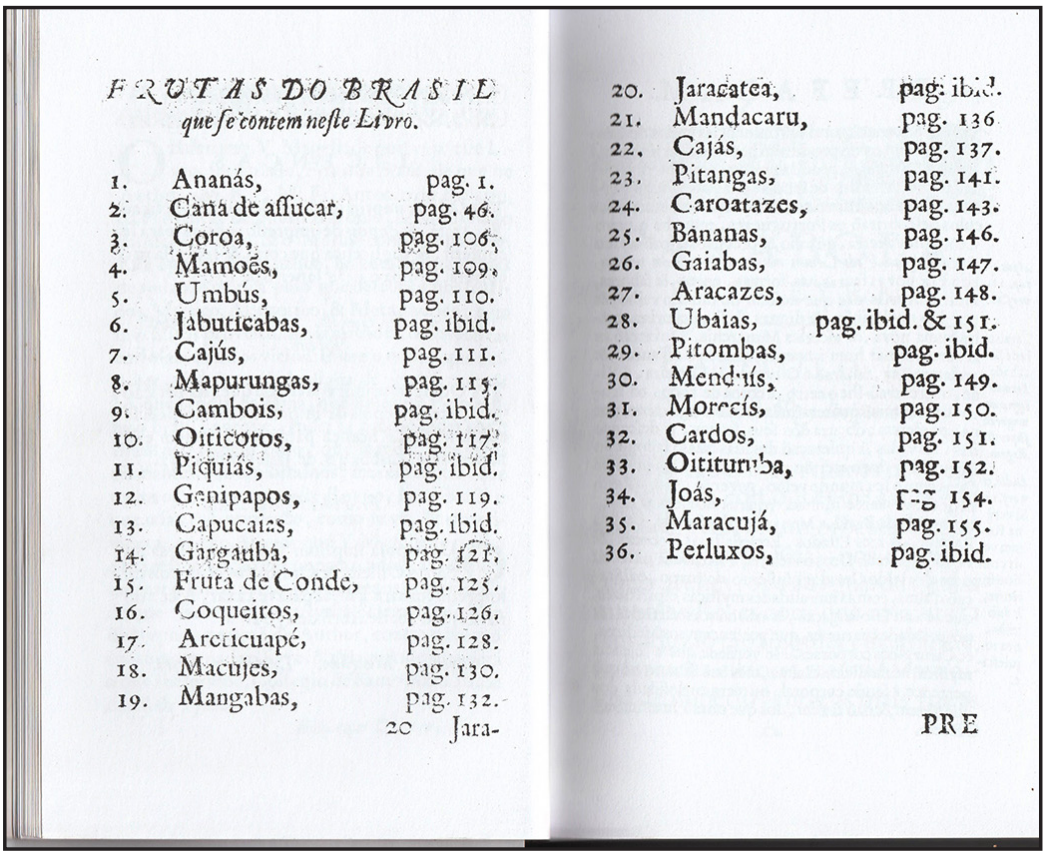

Mas, como afirma Holanda, "só a partir de Simão de Vasconcelos, quando a simples notícia dela já tinha inspirado até poetas marinistas na ltália, é que verdadeiramente principiam, entre nós, os arroubos extáticos diante da flor milagrosa". ${ }^{15}$ Padre Simão de Vasconcelos, nascido em Lisboa e membro da Companhia de Jesus, defensor da tese de que o paraíso terreal se localizava no Brasil, descreve longamente a flor e fruta em seu livro Notícias curiosas e necessárias das coisas do Brasil, publicado em Lisboa em 1668:

$\bigcirc$ outro portento das ervas, graça dos prados, brinco da natureza e devoção da piedade cristã, é aquela a que chamam os portugueses erva da Paixão, os índios maracujá, os casteIhanos de Nova Espanha granadilla. [...] A flor é o mistério único das flores. Tem o tamanho de uma grande rosa, e neste breve campo, formou a natureza um como teatro dos mistérios da redenção do mundo. Lançou por fundamento cinco folhas mais grossas, no exterior verdes, no interior sobrosadas: sobre estas, postas em cruz, outras cinco purpúreas [..]. E logo deste como trono sanguíneo, vai armando um quase pavilhão feito de uns semelhantes a fios de roca, com mistura de branco. Outros the chamarão coroa, outros, molho de açoutes aberto, e tudo vem a ser. No meio deste pavilhão, ou coroa, ou molho, se vê levantada uma coluna 
16. Vasconcelos (1668, p. 254).

17. Rosário (2008, p. 158).

18. Holanda (2000, p. 286). branca, como de mármore, redonda, quase feita ao torno, rematada para mais graciosa com uma maçã ou bola, que tira a ovada. Do remate desta coluna, nascem cinco quase expressas chagas, distintas todas e penduradas cada qual de seu fio, tão perfeitas, que parece as não poderia pintar noutra forma o mais destro pintor: senão que em lugar de sangue tem por cima como um pó sutil, ao qual se aplicais o dedo, fica nele pintada a mesma chaga, formada do pó, como com tinta se pudera formar. Sobre a bola ovada do remate, se veem três cravos perfeitíssimos, as pontas nas bolas, os corpos e cabeças no ar: mais cuidareis que foram ali pregadas de indústria, se a experiência não vos mostrara o contrário. A essa flor chamam por isto flor da paixão, porque mostra aos homens os principais instrumentos dela, quais são: coroa, coluna, açoites, cravos, chagas. ${ }^{16}$

Podemos ver, pelos comentários, que vão se tornando mais prolixos e arrebatados ao longo do tempo, o processo de apropriação da flor ao imaginário cristão pelos missionários franciscanos e jesuítas, cuja simbologia, ao tempo da publicação da obra de Frei Rosário, iá havia se tornado convencional. A simbologia da flor de maracujá foi estabelecida a partir de analogias entre suas formas e os símbolos da paixão de Cristo: os três estigmas corresponderiam aos três cravos que prenderam Cristo na cruz; as cinco anteras representariam as cinco chagas; as gavinhas seriam os açoites usados para o martírio de Cristo; e, finalmente, no formato da flor, seria visível a imagem da coroa de espinhos levada por Cristo para $\mathrm{O}$ ato de crucificação. A cor roxa simbolizaria o sangue derramado por Jesus Cristo, usada nos rituais cristãos durante a Semana Santa. Frei Rosário a descreve nos seguintes termos:

Chegamos a falar da excelente fruta do maracujá, que se não é a rainha é a duquesa das frutas pela flor com que a natureza a enobreceu e singularizou sobre todas as frutas e flores da terra; pintou o criador ao vivo nesta misteriosa flor a lamentável tragédia da sua Paixão, a coluna, os azorragues, os cravos, as chagas, a coroa, o sangue, com tanta perfeição e viveza, que por isso se chama a flor da Paixão, porque como flor expirou o Salvador do mundo no Monte Calvário; como flor morreu inclinando a cabeça, para que com a parábola da flor celebremos a Paixão de Cristo, e façamos memória do maior benefício, que devemos a Deus, coroando a obra da Monarchia das frutas do Brasil com a flor que produz a mesma terra para glória do Criador, lembrança e agradecimento do Redentor. ${ }^{17}$

Apesar do apelo que a flor do maracujá trazia a uma leitura cristã da natureza do Novo Mundo, Frei Rosário elegeu outra fruta como símbolo maior de sua pregação. Uma vez que sua argumentação se baseava na proposta de substituir as flores no Sagrado Rosário de Nossa Senhora (terço) pelas frutas, levando-o a pregar a superioridade destas, sua escolha recaiu sobre o abacaxi, fruta que sobressaiu nas descrições dos viajantes que visitaram o país desde os primeiros relatos, sendo considerada, quase de forma consensual, como a rainha das frutas brasileiras. Segundo Holanda, referindo-se a Frei Rosário e sua predileção pelo ananás, "tão fortemente o amou e venerou o visitador e missionário capucho, que não teve dúvidas em santificá-lo, ao lado do maracujá, fruta e flor, como se as suas reais insígnias devessem prevalecer sobre aqueles símbolos piedosos da flor-da-paixão". ${ }^{18}$ 
A fama e simbologia do abacaxi nos textos sobre o Brasil é anterior e maior que a de qualquer outra fruta, flor ou espécie da flora brasileira descrita, rivalizando, no período colonial, com o pau-brasil e com a cana-deaçúcar (introduzida no país pelos portugueses em 1532), espécies que movimentaram a economia da colônia nos primeiros séculos. Nos relatos de viagem publicados no século XVI pelos franceses André Thevet (Singularidades da França Antártida, de 1557) e Jean de Léry (Viagem a terra do Brasil, de 15781, a fruta já era descrita como preferida sobre todas as outras do país por sua doçura e sabor. Thevet oferece uma das primeiras ilustrações da fruta, e a descreve como semelhante à pinha:

O ananás é da grossura de uma abóbora média, sendo semelhante, exteriormente, à pinha, como se poderá verificar na gravura ao lado. Quando amadurecido, se torna amarelo. É maravilhosamente excelente, não só por sua doçura, como por seu sabor, sendo assim como o mais delicado açúcar, senão melhor. Não se pode transportar essa fruta para a Europa, a não ser em conserva, pois, quando sazonada, não tem muita duração. Além disso, não possui nenhum caroço, reproduzindo-se por intermédio dos renovos, como se faz em França com os enxertos. Antes, todavia, de amadurecer, é o ananás tão áspero que pode ferir a boca. A folha dessa planta, quando crescida, assemelha-se à de um junco bem grande. ${ }^{19}$

Jean de Léry, por sua vez, ao elencar as frutas e ervas do Brasil, decide começar pelo abacaxi, por considerá-lo dos mais úteis e reputá-lo o fruto mais saboroso da América:

Quanto às plantas e ervas que agora quero mencionar, começarei por aquela cujos frutos e efeitos me parecem mais úteis. Em primeiro lugar vou assinalar a planta que produz o fruto chamado ananá. Assemelha-se à espadana, tendo as folhas um pouca côncavas, estriadas nos bordos e muito parecidas com as do aloés. Cresce em touceiras, como grandes cordas, e o fruto, do tamanho de um melão mediano e do feitio da pinha, sai da planta como as alcachofras, sem pender para os lados. Ao amadurecer torna-se amarelo azulado e rescende tão ativamente a framboesa que de longe o sentíamos nas matas onde cresce; é muito doce e o reputo o fruto mais saboroso da América. ${ }^{20}$

Em sua ilustração da fruta, Léry se inspira na imagem apresentada no livro de Thevet, mas a insere como um detalhe na paisagem, de acordo com as convenções do retrato etnográfico. Se Léry inicia sua descrição pela famosa fruta, o português Gabriel Soares de Sousa, no seu relato de 1587, adota a estratégia inversa, descrevendo por último o abacaxi, para evitar, segundo o autor, que os leitores percam o interesse pelas outras frutas após se encantarem com as qualidades do ananás, ao qual dedica um capítulo inteiro. Sousa descreve longamente a planta, sob o ponto de vista da história natural, explicitando seu processo evolutivo, utilidades e características físicas, mas sem apontar nenhuma simbologia além de classificá-la como a primeira das frutas do Novo Mundo, enfatizando que nenhuma outra fruta da Espanha pode the ser comparada "na formosura, no sabor e no cheiro". ${ }^{21}$ 
22. Gandavo (2008, p. 64).

23. Cardim (1939, p. 256).

24. Salvador (1918, p. 32).

25. Vasconcelos (1668, p. 243).

26. Rosário (2008, p. 1).
O cronista português Pero de Magalhães Gandavo, que escreveu por volta de 1570 seu Tratado da terra do Brasil, publicado apenas em 1826, não fez nenhuma referência ao maracujá ou à sua flor, e descreveu o abacaxi apenas por seu aspecto e uso, notando sua sempre lembrada superioridade sobre as outras espécies - "excedem no gosto a quantas frutas há neste reino", mas encontrou uma simbologia cristã num tipo específico de banana: "Estas pequenas têm dentro em si uma cousa estranha, a qual é que quando as cortam pelo meio com uma faca ou por qualquer parte que seja acha-se nelas um sinal à maneira de crucifixo, e assim totalmente o parecem". ${ }^{22} \bigcirc$ missionário jesuíta Fernão Cardim, cujos textos escritos entre 1583 e 1601 foram publicados na íntegra somente em 1925, já alcunhava a fruta do abacaxi por sua realeza l"O ananás é fruta real"23), mas se absteve de maiores simbologias em sua descrição, saudando-o por seu gosto e aparência, assim como o maracujá, cuja planta é citada sem referência às suas flores.

Frei Vicente de Salvador, que também notara a simbologia da flor do maracujá, descreve o abacaxi nos seguintes termos:

O mesmo tem outra planta que produz os ananases, fruta que em formosura, cheiro e sabor excede todas as do mundo, alguma tacha the põem os que têm chagas e feridas abertas, porque lhas assanha muito se a comem, trazendo ali todos os ruins humores, que acha no corpo: porém isto antes argue a sua bondade, que é não sofrer consigo ruins humores, e purgá-los, pelas vias, que acha abertas, como o experimentam os enfermos de pedra, que tha desfaz em areias, e expele com a urina, e até a ferrugem da faca, com que se apara, a limpa. ${ }^{24}$

Além de retificar seu status de fruta soberana entre todas as outras, ainda que sem referências às suas insígnias, Frei Vicente cita suas qualidades curativas. Curiosamente, Padre Simão de Vasconcelos, que tanto se alongou em sua descrição simbólico-cristã da flor do maracujá em sua defesa do paraíso terreal no Brasil, abstém-se de fazer quaisquer referências à simbologia da realeza do abacaxi, cuja coroa é por ele descrita como "um penacho, ou grinalda de cores aprazíveis", ainda que o considere "uma espécie muito galante, e causa de louvar o autor da natureza", e se mantém nos aspectos utilitários da fruta. ${ }^{25}$

Para Frei Rosário, o abacaxi se coloca sobre todas as outras frutas, não só da América, como do mundo, não apenas por seu sabor e beleza, mas por sua rica simbologia:

Nasce o ananás com coroa como Rei, na casca, que parece um brocado em pinhas, tem a roupa real; nos espinhos como arqueiros a sua guarda; pelas insígnias reais com que a natureza o produziu tão singular, de grande e formosa estatura, tem a forma digna de império, entre as mais frutas do universo. 26

Frei Rosário segue descrevendo as características da fruta e, remetendose ao comentário de Frei Vicente de Salvador, avalia suas qualidades digestivas segundo critérios morais: "É príncipe perfeito, porque é severo e suave, sendo para 
o gosto a maior delícia; sendo tão gostoso, suave e deleitável, é muy severo,

27. Rosário (2008, p. 2, 5).

28. Oliveira (2013, p. 5). da suavidade (do seu aprazível gosto), com a severidade (de sua acidez que ataca as feridas e mesmo corrói o ferro da faca que the corta) torna-o exemplo para os príncipes: "Seja, pois, rei dos pomos quem sabe temperar as doçuras com os rigores, dando aos governos do mundo máximas e leis divinas e humanas". ${ }^{27}$

Como podemos ver, desde os primeiros relatos dos viajantes e missionários, o abacaxi foi elevado ao posto de rei das frutas, do Brasil, da América e quiçá de todo o mundo, principalmente por sua beleza e sabor. Suas insígnias reais encontradas em sua aparência exótica, no entanto, não são ressaltadas nos relatos dos séculos XVI e XVII lainda que Cardim o tenha chamado de "fruta real"), mas apenas suas qualidades de sabor, aparência agradável e utilidades medicinais. Até onde conseguimos pesquisar, a primeira descrição do abacaxi brasileiro por suas insígnias reais (coroa, cetro, brocado e guardas) encontra-se em Frei Rosário, no seu livro de 1701 . No entanto, o missionário seria logo seguido pelos já citados Botelho de Oliveira e Frei Itaparica. Botelho assim descreveu o abacaxi em sua obra de 1705:

Entre as fruitas merece nome, e brio;

Tem nas pevides mais gostoso agrado,

Do que açúcar rosado;

É belo, cordial, e como é mole,

Qual suave manjar todo se engole.

Vereis os ananases,

Que para rei das fruitas são capazes;

Vestem-se de escarlata

Com majestade grata,

Que para ter do Império a gravidade

Logram da croa verde a majestade;

Mas quando têm a croa levantada

De picantes espinhos adornada,

Nos mostram que entre Reis, entre Rainhas

Não há croa no Mundo sem espinhas.

Este pomo celebra toda a gente,

É muito mais que o pêssego excelente,

Pois the leva aventagem gracioso

Por maior, por mais doce, e mais cheiroso. ${ }^{28}$

Frei ltaparica, por sua vez, descreve a fruta em sua obra de 1769:

LIV

No ananás se vê como formada

Uma coroa de espinhos graciosa, 
Os dois autores, Botelho e Itaparica, também citam o maracujá em seus poemas nativistas, mas descrevem apenas sua fruta e, assim como as menções ao abacaxi, não apresentam nenhuma conotação religiosa. Esta vai ser estabelecida por Frei do Rosário em sua obra Frutas do Brasil, na qual o elege rei dos pomos, não apenas por suas qualidades de sabor e medicinais, mas por sua simbologia religiosa.

Ao eleger o abacaxi rei dos pomos, Frei Rosário utiliza a imagem das frutas tropicais como símbolo do Brasil e da América, contrapondo-a à imagem da Europa católica, representada pelas rosas. Sua proposta é a de criar uma versão do rosário sagrado para o Novo Mundo e, se, no Velho Mundo, Nossa Senhora criou seu rosário pela imagem das rosas, no Brasil o sagrado rosário deveria tomar a forma de frutas. As frutas representariam o aspecto pragmático, por servirem de alimento, enquanto as rosas, desejadas por sua beleza e aroma, seriam efêmeras. Ao mostrar a superioridade das frutas sobre as flores, do útil sobre o agradável, Frei Rosário buscou conciliar as dádivas da natureza do Novo Mundo à ideia de um paraíso terreal. Tal representação saiu das páginas dos livros para decorar, ainda que de forma acanhada, altares e paredes dos templos católicos construídos no Brasil durante seu período colonial. Passaremos agora, portanto, a analisar a presença desses elementos nativos, especialmente as frutas tropicais, na iconografia religiosa que se desenvolveu no período colonial brasileiro.

Frutas tropicais na arte sacra

Apesar de encontrarmos algumas poucas representações de figuras indígenas, e mesmo de fauna nativa, a principal originalidade temática na iconografia barroca produzida sobre a América Portuguesa vai se manifestar na representação das frutas tropicais junto às tradicionais videiras, peras e folhas de acanto na decoração das igrejas. Além do aspecto plástico das frutas e da existência de uma tradição anterior no uso de frutos como ornamentos, inclusive nas igrejas católicas, sua interpretação religiosa e simbólica, pregada por Frei Rosário e presente em vários outros textos da época, como analisamos, certamente teria respaldado seu aproveitamento decorativo nos templos. Entre as frutas representadas, o caju e o abacaxi se destacam, tanto por sua beleza plástica quanto pela facilidade de sua representação, devido às formas originais e reconhecíveis, assim como por seu simbolismo. 
No mencionado levantamento das ocorrências de representações de frutas tropicais na decoração de igrejas do período colonial brasileiro, foram encontrados exemplos em pinturas nos tetos de sacristias, entalhes em madeira nos retábulos e esculpidas em pedra em frontispícios, em obras datando dos séculos XVII e XVIII, compreendendo cidades das Regiões Nordeste e Sudeste do país. Curiosamente, em nossa pesquisa, não foi encontrada nenhuma ocorrência dessa temática na produção sacra do chamado Barroco Mineiro, que se utilizou de outros recursos além da temática nativa em sua originalidade lainda que encontremos a presença de anjos mulatos nas pinturas de Manuel da Costa Ataíde).

Os exemplos mais antigos de representações de frutas tropicais na arte colonial brasileira foram notados no célebre artigo de Lúcio Costa, publicado na revista do IPHAN de 1941, sobre a arquitetura dos jesuítas no país. No artigo, Costa aponta a presença de representações de frutas nos altares laterais da basílica jesuíta de Salvador, Bahia, e no retábulo da capela de Nossa Senhora da Conceição de Voturuna, em Santana do Parnaíba, São Paulo. Esses retábulos se inscrevem na primeira e segunda fase da arte barroca no país, segundo a classificação de Costa, que a divide, no que se refere à talha e composição dos retábulos, em quatro períodos: 1) fins do século XVI e início do XVII (maneiristas ou protobarrocos); 2) seiscentistas; 3) início e meados do século XVIII; e 4) segunda metade do século XVIII (Barroco Mineiro). ${ }^{30}$ Entre os retábulos jesuítas remanescentes do primeiro período, encontram-se o altar-mor da igreja de São Lourenço dos Índios, em Niterói, e os altares laterais da Basílica de Salvador.

- retábulo da igreja de São Lourenço dos Índios apresenta belos entalhes de pendões de frutas. Apesar da controvérsia quanto à origem brasileira ou europeia desse retábulo, as frutas representadas parecem não fazer nenhuma referência direta à natureza brasileira. Essa obra, considerada por Costa como um autêntico exemplar do estilo jesuíta português, teria inspirado versões populares brasileiras em retábulos seiscentistas, dos quais teriam restado apenas dois, o da capela de Santo Antônio, em São Roque, e o da capela de Nossa Senhora da Conceição de Voturuna. $\bigcirc$ retábulo de Voturuna nos interessa por se inspirar nos arranjos de frutas do retábulo da igreja de São Lourenço dos Índios para criar uma versão manifestamente local, representando dois pendões, cada um composto por quatro frutas, entre as quais se podem notar claramente um caju e um abacaxi. As outras frutas também representariam espécies nacionais, apesar de não identificadas. A capela de Voturuna foi construída em 1687, período provável da produção do retábulo. Para Benedito Lima de Toledo, essas "são peças às vezes designadas como 'primitivas', dado o relevo baixo que caracteriza sua talha e pela impressão de serem reinterpretação feita de memória dos retábulos eruditos de inspiração renascentista". ${ }^{31}$ Lúcio Costa o descreve:

Na composição de Voturuna os pormenores de perfilatura e de ornamentação também reproduzem, de memória, os ornatos e perfis dos modelos portugueses, vendo-se, porém, entre as frutas amarradas por uma faixa - motivo europeu então na moda e já encontrado no frontão 
32. Costa (1941, p. 54).

33. Costa (1941, p. 63).

34. Flexor (2010).

35. Flexor (2010, p. 17)

36. Bazin (1956, p. 258) do retábulo da igreja de São Lourenço dos Índios e que encontraremos mais tarde nos vestígios da cantaria da igreja de Santo Ângelo das Missões, no Rio Grande do Sul - dois minúsculos abacaxis. ${ }^{32}$

autor não sugere uma interpretação para a presença dos abacaxis no retábulo jesuíta, além de não notar os cajus também presentes no arranjo (além de duas outras frutas não identificadas), mas os considera como sinais da produção desses retábulos em terras brasileiras, diferentemente das outras peças remanescentes do mesmo período, que teriam sido importadas de Portugal. Segundo ele,

[...] não são, pois, estes retábulos paulistas simples cópias inábeis, mas, muito pelo contrário, legítimas 'recriações', podendo ser consideradas ... como das mais antigas e autênticas expressões conhecidas da arte 'brasileira', em contraposição à maior parte das obras luso-brasileiras dessa época. ${ }^{33}$

Outra referência feita por Costa à representação de frutas tropicais encontra-se no retábulo das Virgens Mártires, situado na capela lateral da igreja do antigo colégio dos jesuítas, atual Basílica de Salvador. Esse retábulo e o dos Santos Mártires são considerados os mais antigos da Basílica, sendo remanescentes da igreja anterior construída no século XVI - segundo Maria Helena Flexor, datam de 1581.34 Apesar de o retábulo fazer parte da primeira fase maneirista, sua parte inferior, na qual aparecem as frutas tropicais entalhadas em madeira, é um acréscimo posterior, datando do século XVII, usado para adequar o antigo altar às proporções do alto pé-direito da nova catedral, o qual, segundo Flexor, remonta ao período em que a nova basílica foi construída, entre 1657 e 1672 . No retábulo das Virgens Mártires, encontramos as frutas tropicais entalhadas em madeira em duas faixas verticais representando cajus, frutos do cacau e uma terceira fruta não identificada (Figuras 3, 4 e 7).

Flexor estima a data da construção do altar-mor da Basílica de Salvador entre 1665 e 1670 - tendo sido executada pelo irmão João Correia - e o caracteriza como de transição do renascimento para o barroco. ${ }^{35}$ As frutas tropicais foram usadas com profusão nas paredes laterais do altar-mor, emoldurando as 18 pinturas, nove de cada lado da parede do presbitério, que representam, em estilo maneirista, a vida de Jesus. Para Germain Bazin, os ornamentos das paredes laterais do altar-mor são de execução posterior a essa estrutura e teriam sido produzidos pelo mesmo ateliê que executou a decoração dos altares relicários dos mártires, com data provável de execução em torno de $1717 .{ }^{36}$

Os entalhes do grandioso altar-mor da Basílica de Salvador apresentam uma riqueza iconográfica que evidencia as frutas brasileiras se juntando a figuras de indígenas e colonizadores, animais e outras alegorias, que mereceriam um estudo à parte. Foram encontradas várias representações das frutas tropicais no altar-mor: além das molduras dos quadros das paredes laterais, como já citamos (Figuras 5 e 6), foram localizadas em duas sereias estilizadas - carregando cestos de frutas - (Figura 8) e em um rico arranjo de frutas tropicais localizado na parte 
mais alta do retábulo, na parede de fundo do camarim (Figuras 9 e 10). $\bigcirc$ entalhe que cobre essa parede do camarim apresenta uma das mais belas ornamentações com frutas tropicais produzidas no barroco brasileiro.

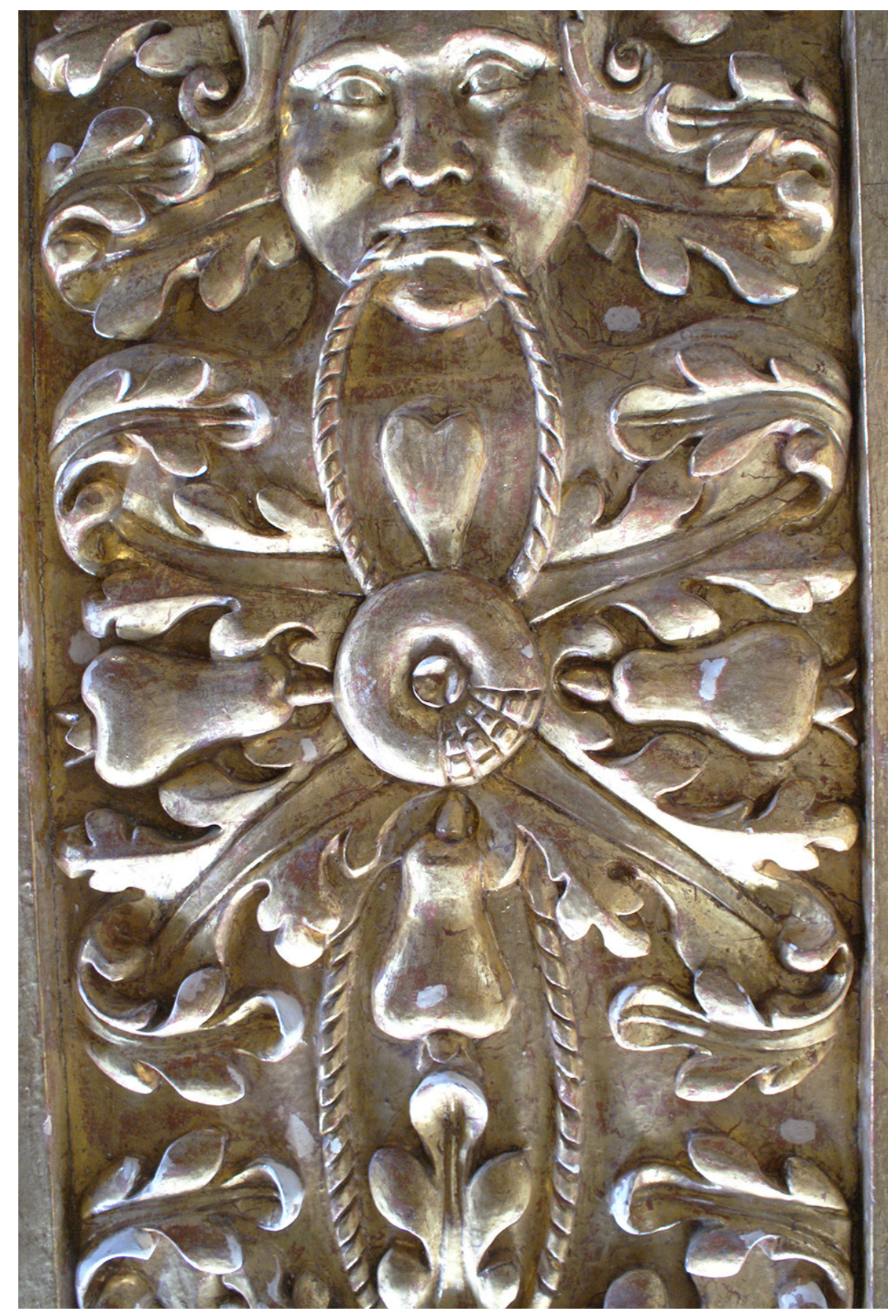

Figuras 3 e 4 - Detalhes do corpo inferior do retábulo das Virgens Mártires, Basílica de Salvador, mostrando representações de frutos do caju, cacau e terceiro não identificado, século XVII. Fotografias do autor 


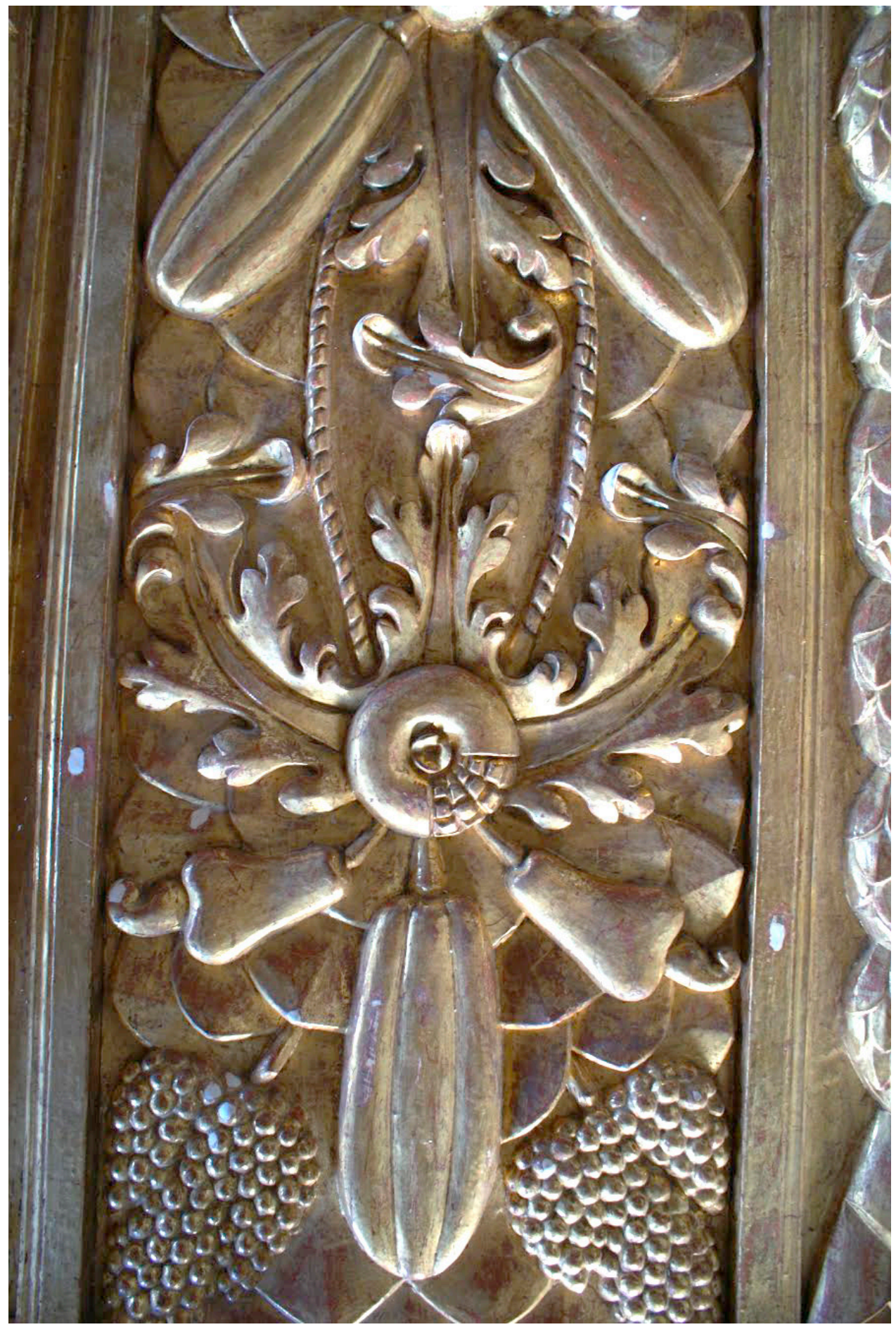

Figura 4 


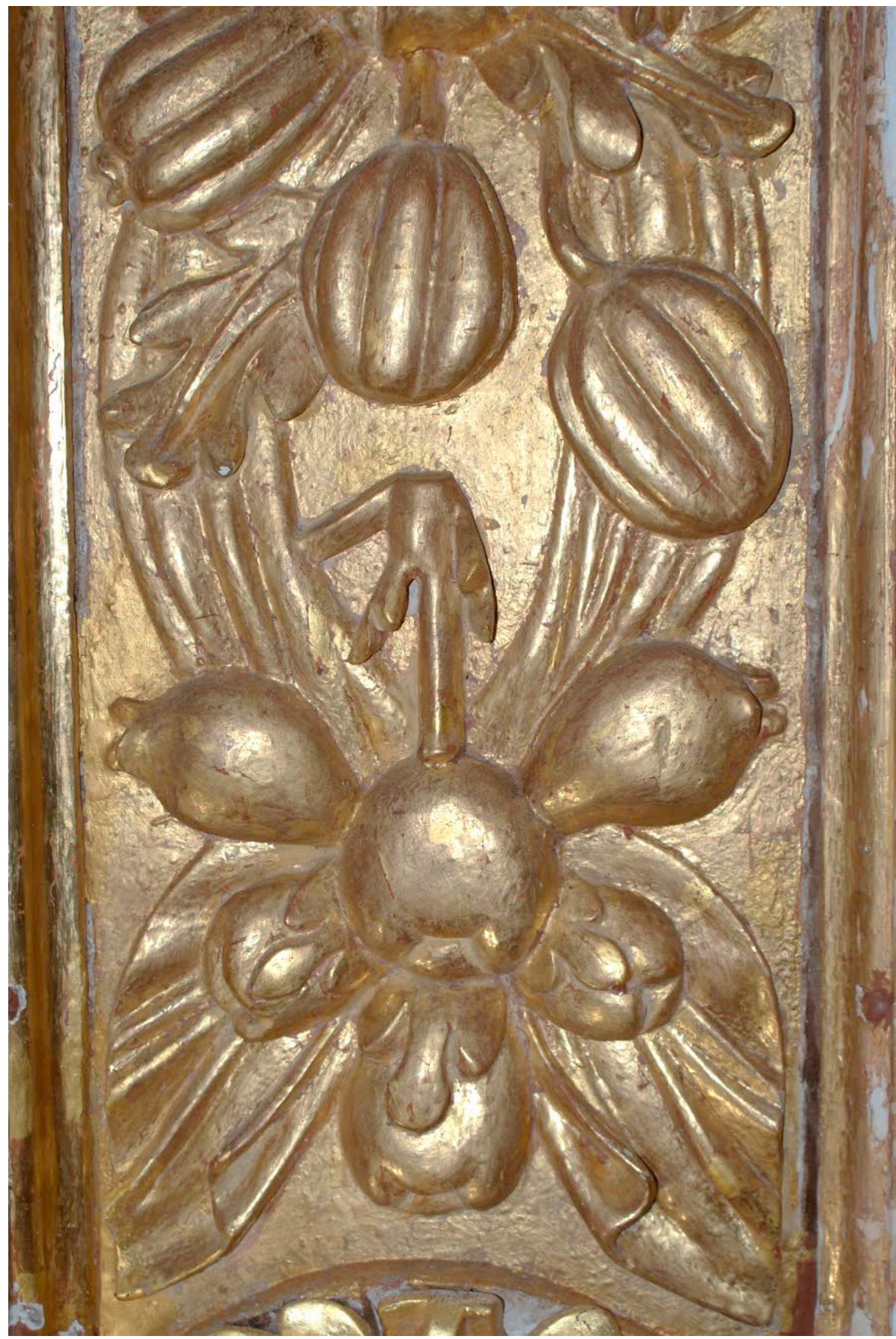

Figuras 5 e 6 - Detalhes das molduras das paredes laterais do altar-mor da Basilica de Salvador, com representações de frutas brasileiras, século XVII. Fotografias do autor 


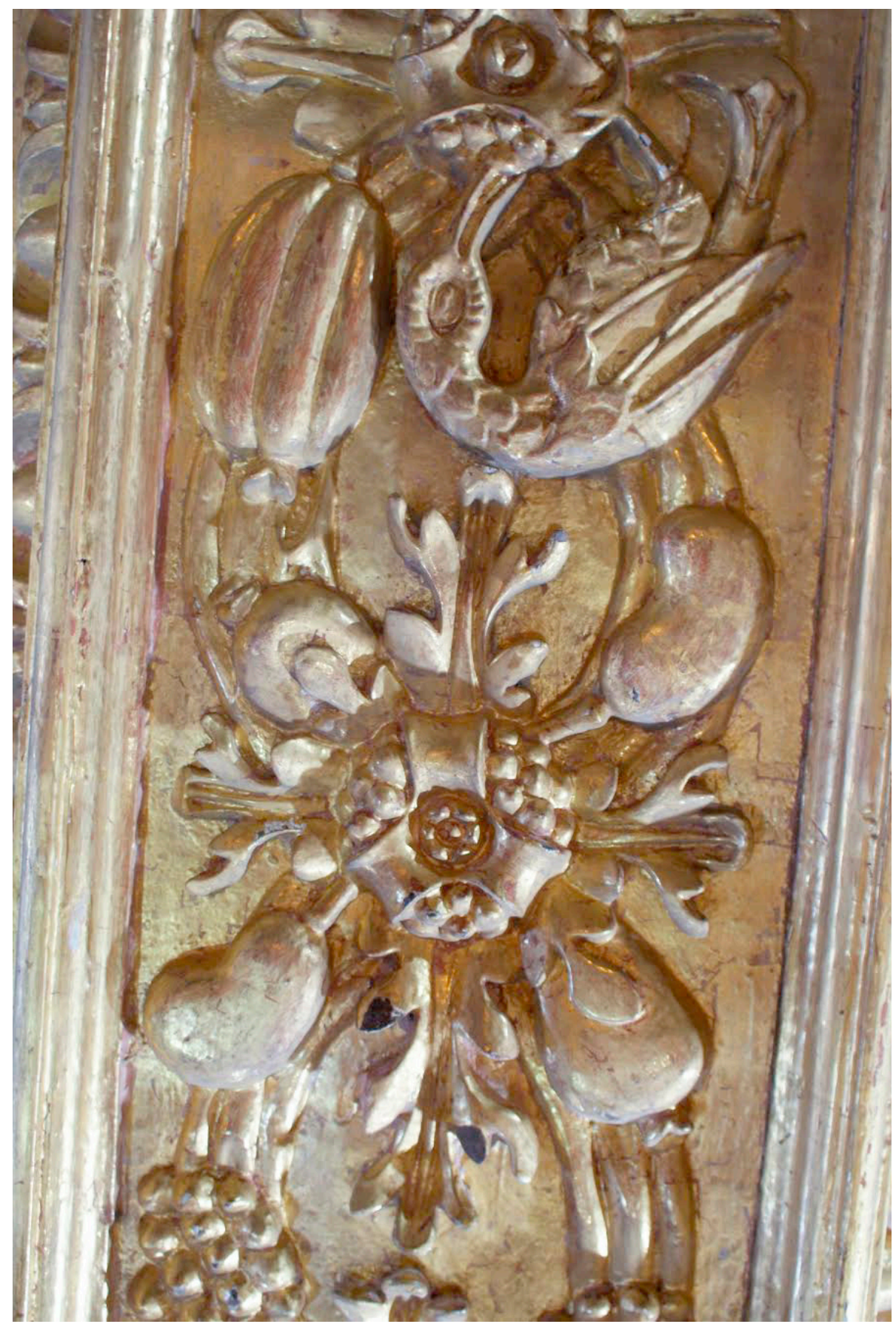

Figura 6 


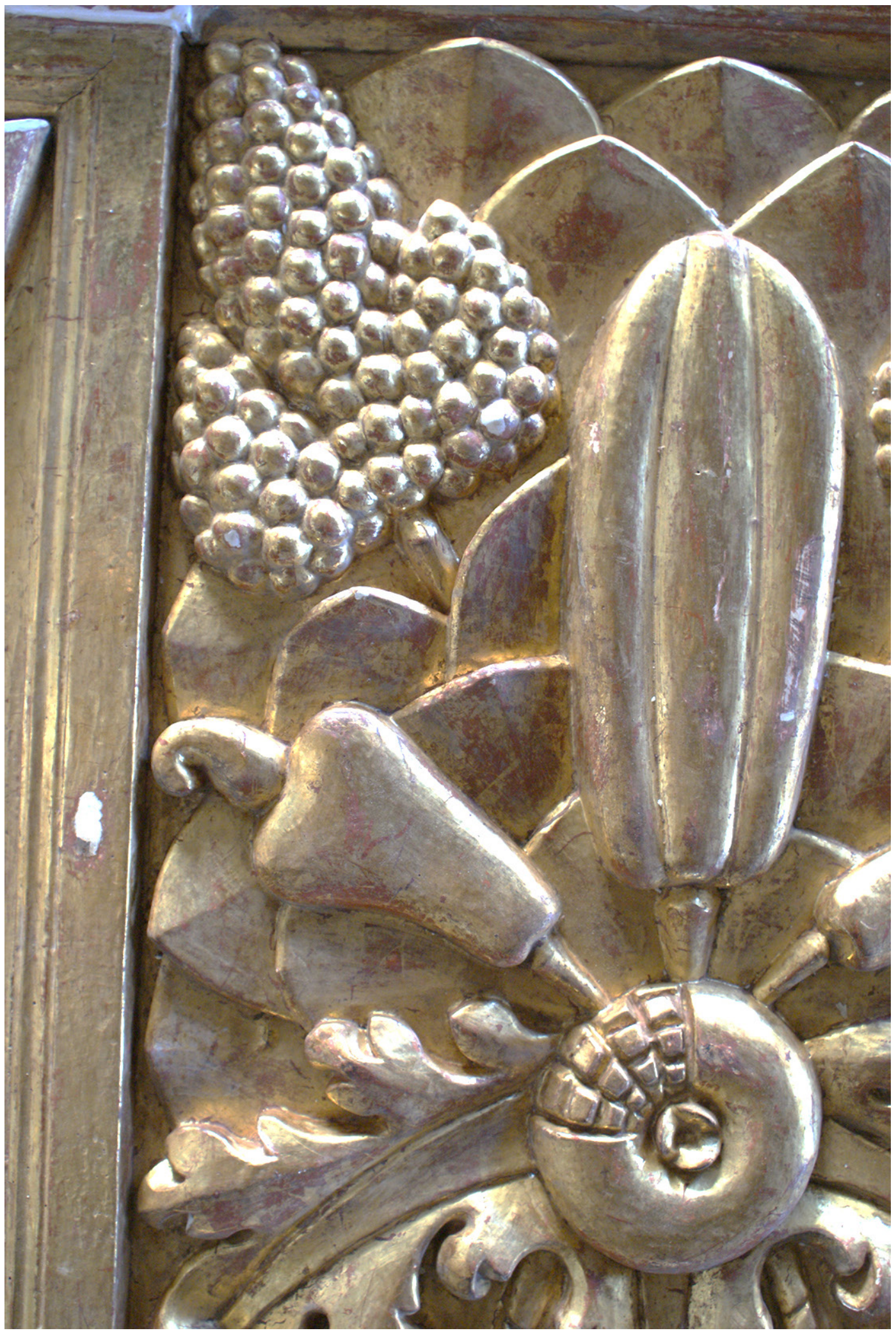

Figura 7 - Detalhe do corpo inferior do retábulo das Virgens Mártires, Basílica de Salvador, c. 1657-1672. Fotografia do autor 


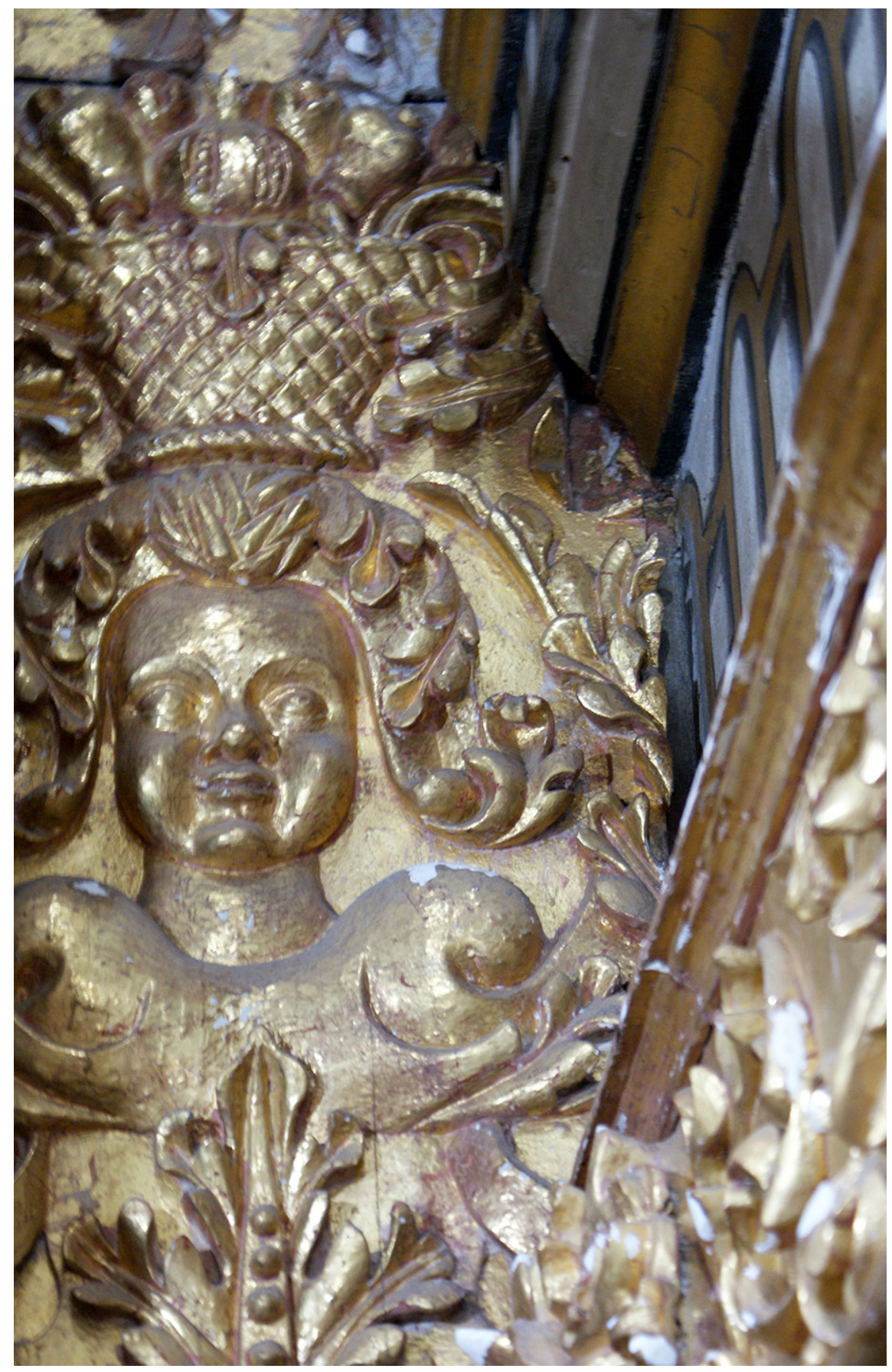

Figura 8 - Detalhe de figura de sereia portando cesto com frutas tropicais, paredes laterais do altar-mor, Basílica de Salvador, século XVII. Fotografia do autor

É curioso encontrar trabalho tão cuidadoso em posição quase inacessível à visão, pela sua localização elevada, indistinguível a olho nu por um observador ao nível do chão, e por permanecer normalmente encoberto por uma imagem do Santíssimo Sacramento. Na foto apresentada (Figura 9), 
é possível notar uma área do painel que não recebeu o douramento em sua última restauração devido exatamente ao encobrimento provocado pela imagem do Santíssimo Sacramento.

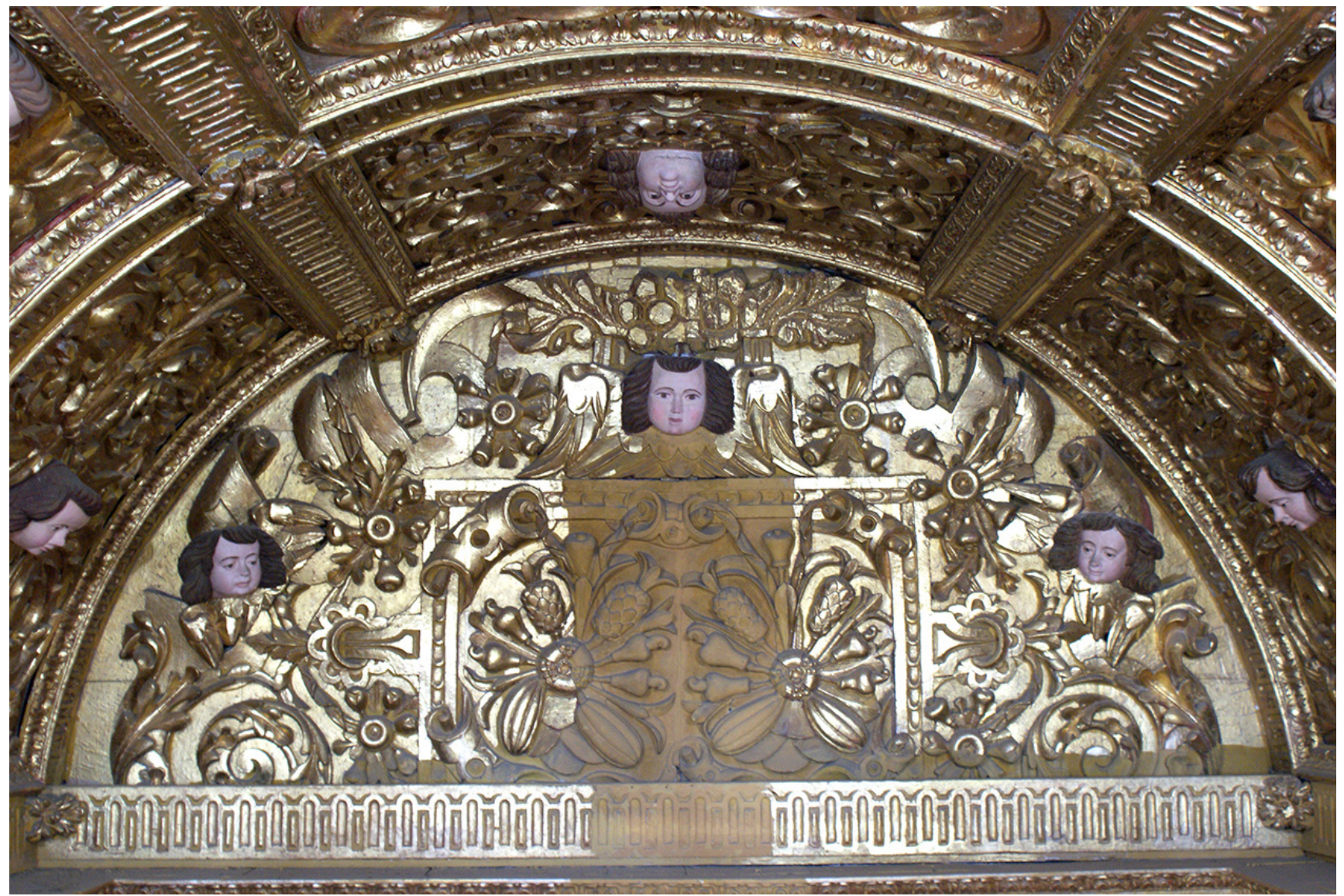

Figura 9 - Painel com representação de frutas tropicais (abacaxi, cacau e caju, ao centro) na parede de fundo do camarim do altar-mor da Baślica de Salvador, final do século XVII. A parte fosca ao centro corresponde ao espaço ocupado pela imagem do Santíssimo Sacramento, que foi deixado sem douramento na última restauração. Fotografia do autor

Completando a ornamentação em temática tropical da Basílica de Salvador, encontramos as pinturas do teto da grandiosa sacristia, representando os missionários da Companhia de Jesus em 21 caixotões com pinturas a têmpera. Realizadas entre 1673 e 1683, segundo Flexor, ${ }^{37}$ as pinturas, de autoria atribuída ao jesuíta português Domingos Rodrigues, apresentam em estilo barroco os retratos dos missionários jesuítas emoldurados em cartelas de bordos recortados e ornamentados com figuras de animais, folhas de acanto, flores e putti. Entre os ornamentos, podemos encontrar abacaxis estilizados (Figuras 11 e 12). Outra igreja jesuíta em que encontramos ornamentação tropical é a

37. Flexor (2010, p. 32) 38. Toledo (2012, p. 168). igreja de Nossa Senhora do Rosário, em Embu, Estado de São Paulo. Datada de 1720, a capela-mor possui teto decorado com pinturas em caixotões arrematados nas quinas com pequenos ornamentos em forma de abacaxis. ${ }^{38}$ 
Além dos jesuítas, os missionários carmelitas e franciscanos que atuaram no país no período colonial também se utilizaram da temática das frutas tropicais na decoração de seus templos e conventos. Na sacristia da igreja de Nossa Senhora das Neves e Ordem Terceira de São Francisco, em Olinda, Pernambuco, o teto é coberto por pinturas, em 15 caixotões octogonais com cenas franciscanas, secundados por oito pinturas menores com naturezas-mortas, entre as quais podemos identificar abacaxis, bananas e cajus, entre outras (Figuras 13, 14 e 15). Possivelmente, são as pinturas do gênero da naturezamorta mais antigas já feitas no Brasil, depois das pintadas pelo holandês Albert Eckhout durante a ocupação holandesa. Encontram-se no convento franciscano mais antigo do Brasil. Sua construção foi iniciada em 1585, com projeto do frei

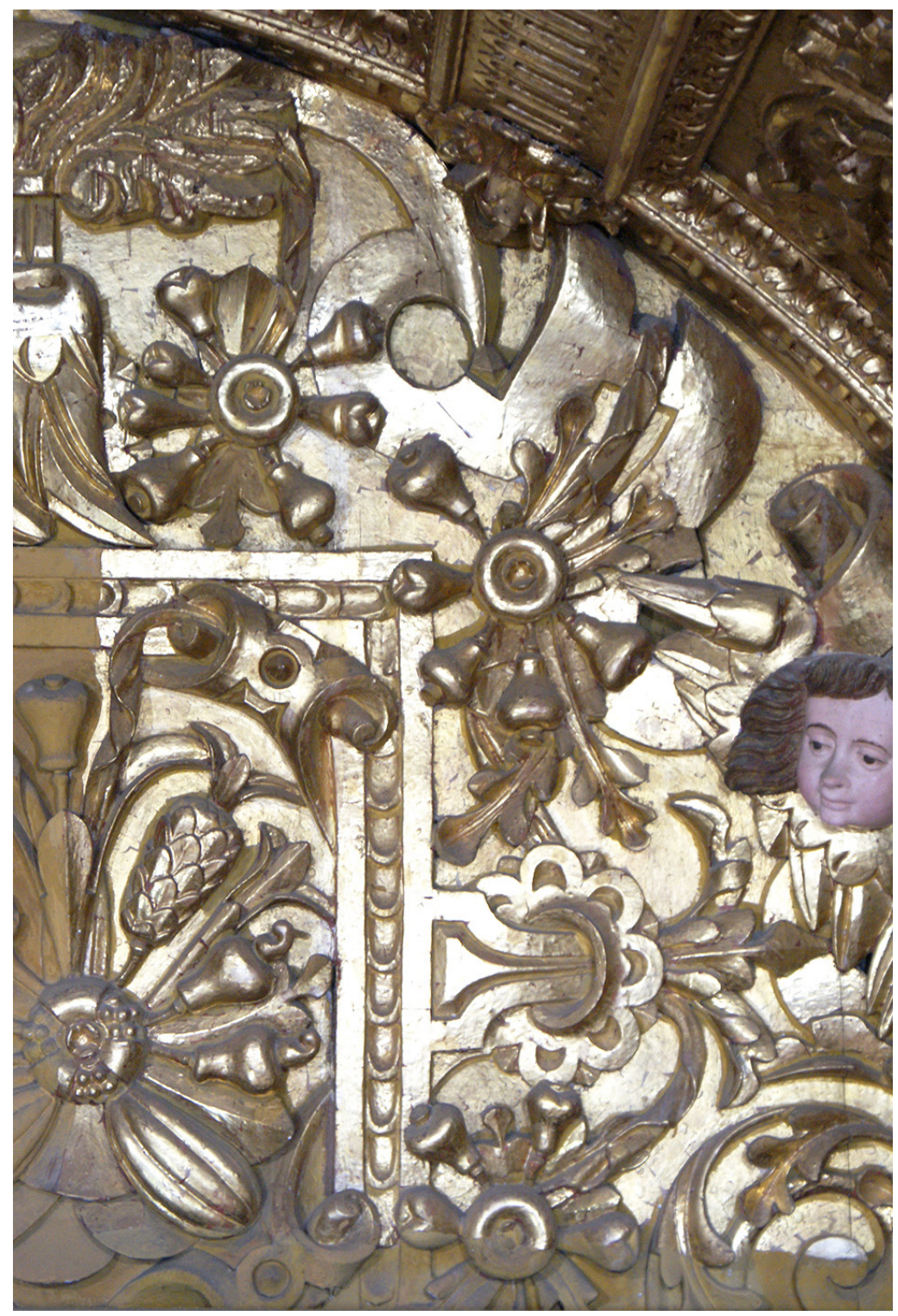

Figura 10 - Detalhe na parede de fundo do camarim do altar-mor da Basílica de Salvador, final do século XVII. Fotografia do autor 
Francisco dos Santos, tendo sido parcialmente destruído pelos holandeses no ano de 1631 e reconstruído no século XVIII. Para Cleide Biancardi, "a sacristia é considerada um dos mais perfeitos e ricos exemplos da arquitetura de interior do barroco português, feito no Brasil no século XVIII". ${ }^{39}$

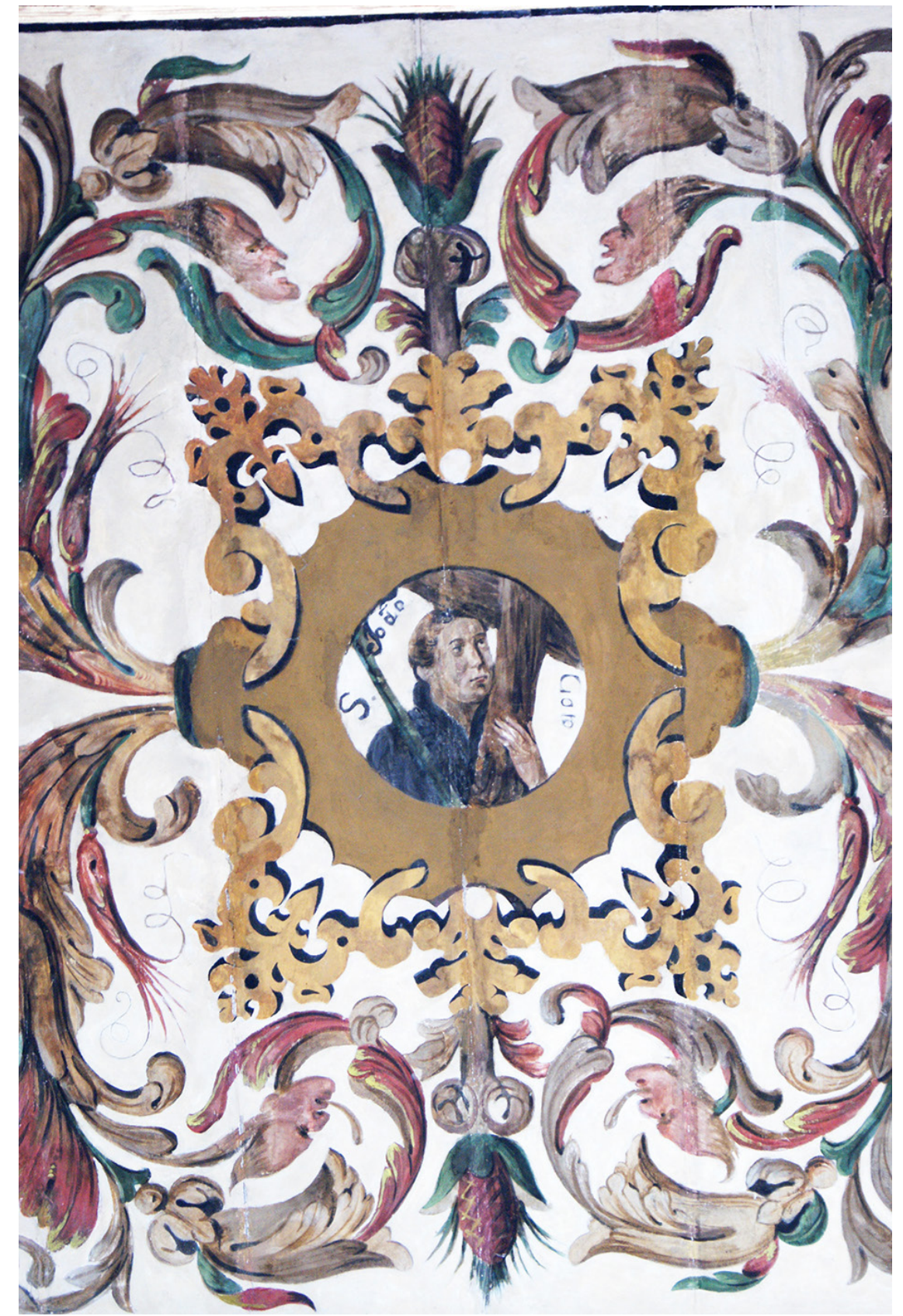

Figuras 11 e 12 - Pinturas do teto da sacristia da Basilica de Salvador com retratos de jesuítas e detalhes de animais e frutas brasileiras estilizadas (abacaxi). Fotografias do autor 


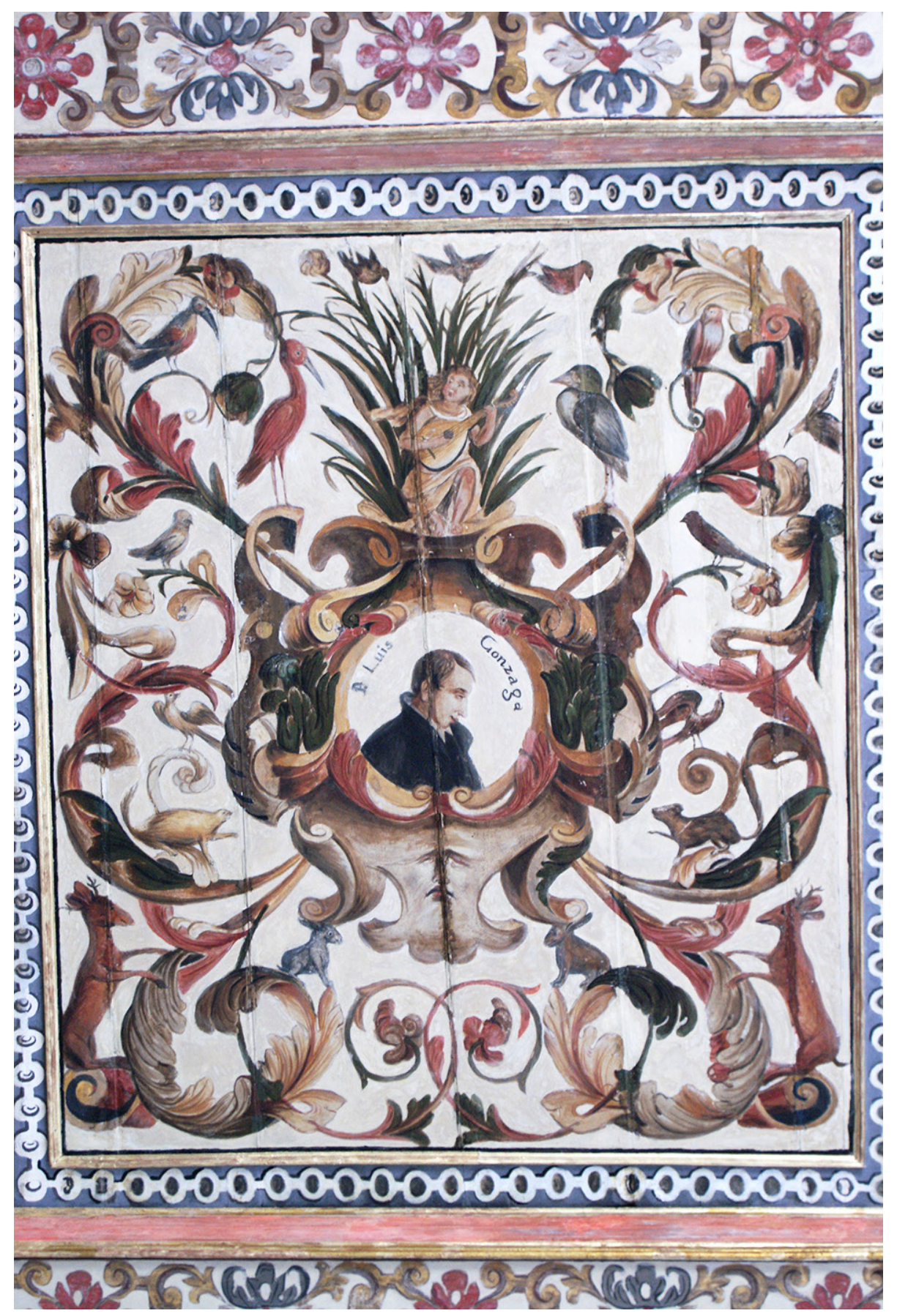

Figura 12 


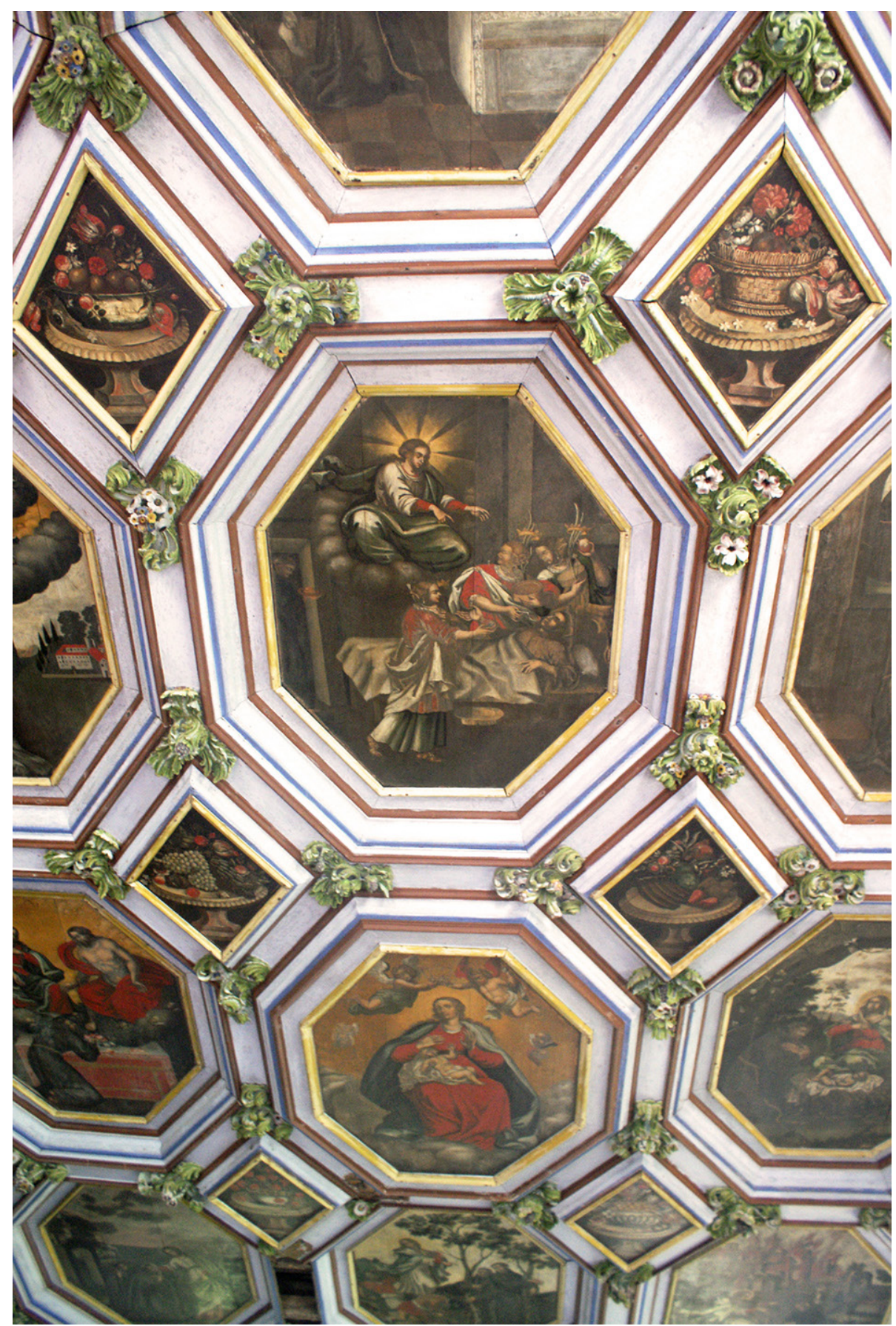

Figura 13 - Teto da igreja de Nossa Senhora das Neves, Olinda, Pernambuco, início do século XVIII. Fotografia do autor 
Finalmente, o teto, pintado à maneira dos tetos barrocos das igrejas luso-brasileiras. São quinze painéis de forma octogonal e oito em forma de losangos, limitados por molduras policromadas. Nos octógonos, a temática dos medalhões refere-se à crônica franciscana; os losangos são pintados com naturezas-mortas, como vasos com flores e frutos brasileiros: cachos de bananas, romãs, peras, cachos de uvas, cajus, abacaxis, melancia, pinhão, cenouras. Há também pássaros do Brasil. É um dos tetos mais originais das igrejas barrocas brasileiras. ${ }^{40}$

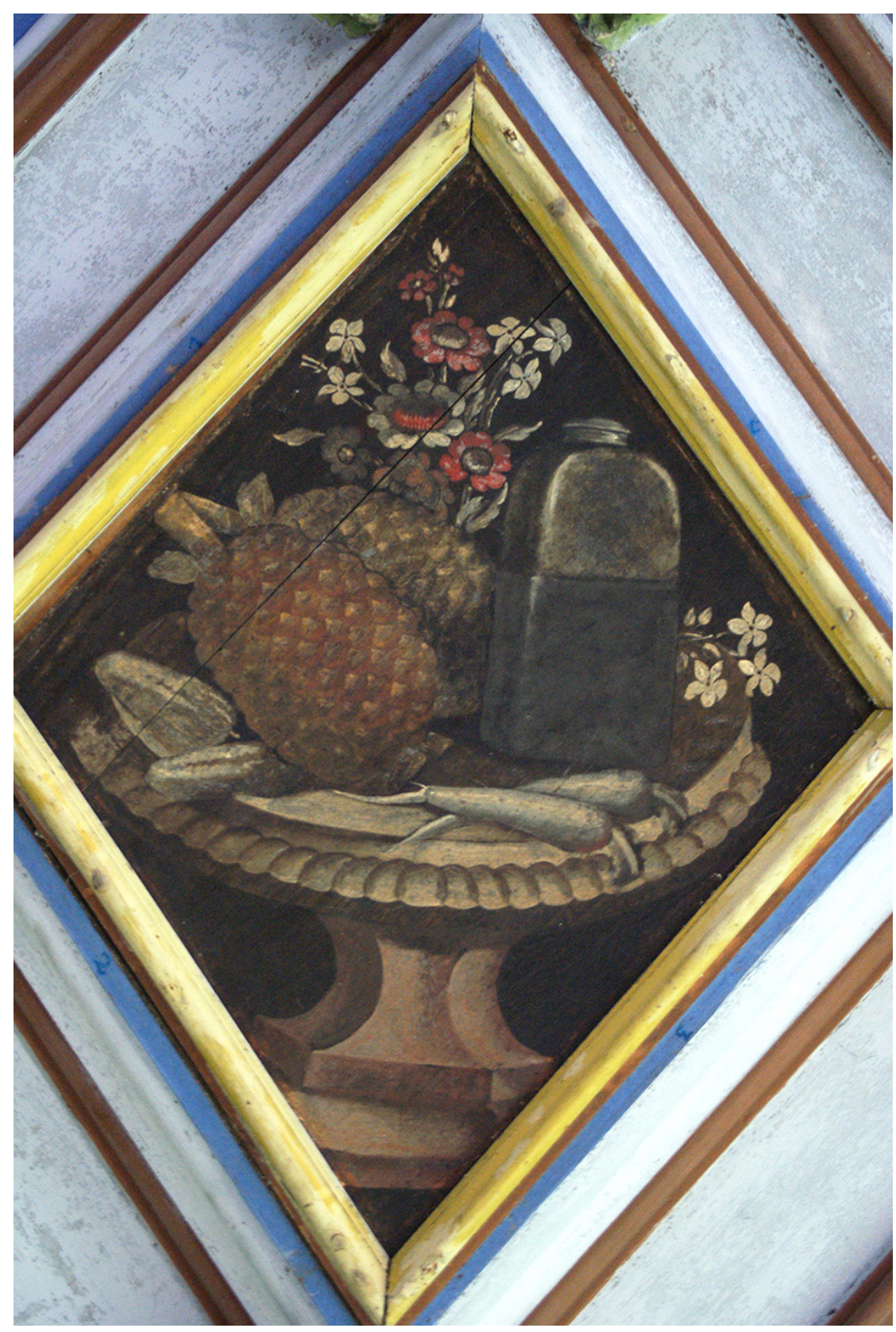

Figuras 14 e 15 - Naturezas-mortas com frutas tropicais na sacristia da igreja de N. Sra. das Neves e Ordem Terceira de São Francisco Olinda, Pernambuco, início do século XVIII. Fotografias do autor. 


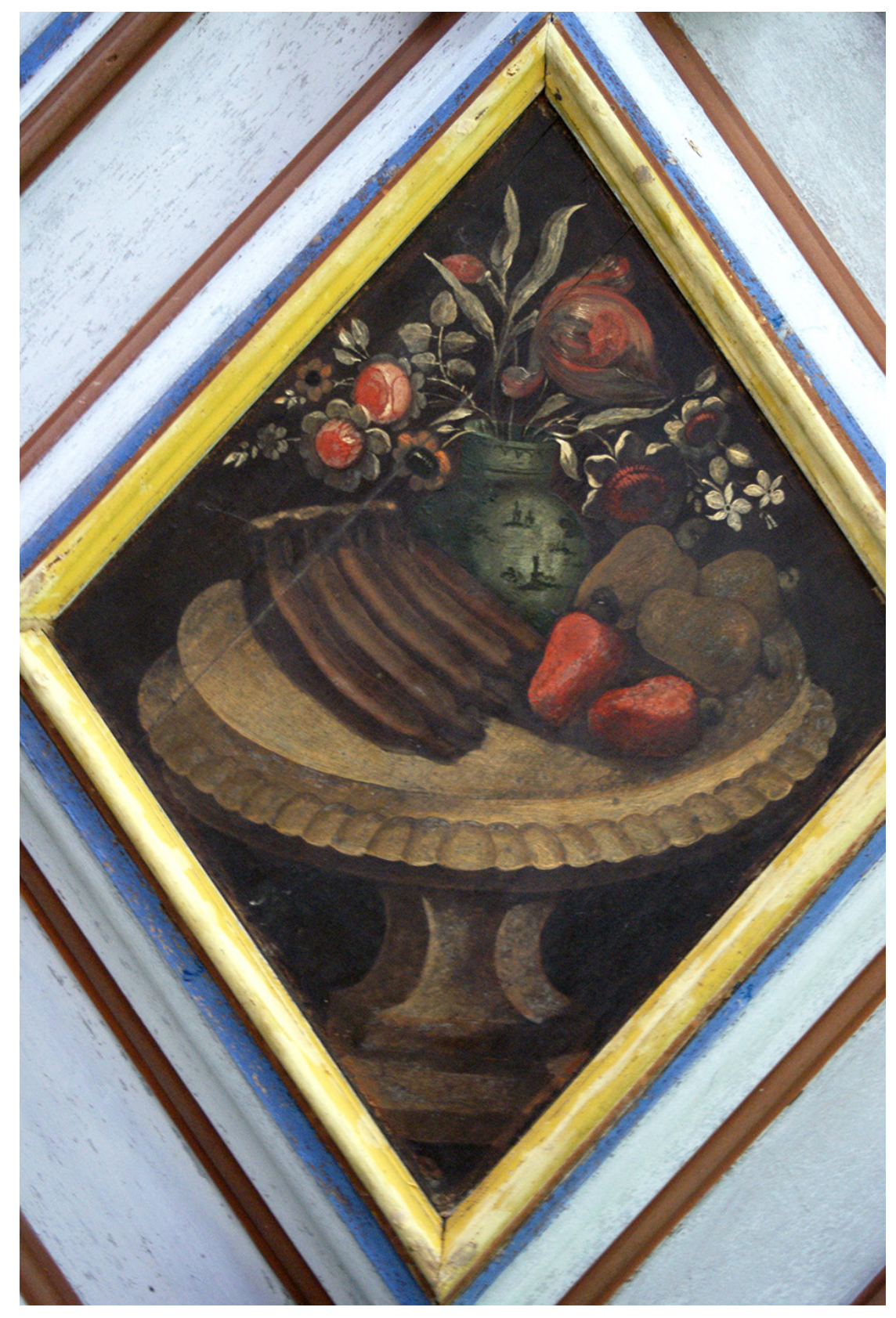

41. Bazin (1956, p. 164).

Figura 15

Na Bahia, encontramos temas da flora nativa na igreja do convento franciscano de Santo do Antônio do Paraguaçu, município de Cachoeira. Germain Bazin aponta frutas tropicais, mamão e abacaxi, esculpidos no frontispício da igreja, de 1686: "Essa ornamentação é inspirada na decoração dos retábulos, onde aparecem uma quinzena de anos antes, na talha da igreja do colégio dos Jesuítas em Salvador, nos altares dos Santos Mártires e das Virgens Mártires". ${ }^{41} \mathrm{Na}$ fachada da igreja franciscana, acham-se, esculpidos em pedra, dois pequenos 
arranjos de frutas pendurados com laços, à moda dos encontrados nos retábulos de Voturuna e da igreja dos Índios, de Niterói. Flexor nota também a presença de frutas tropicais, esculpidas em pedra junto de conchas, folhas de acanto e rosáceas na chamada peanha, ou calvário, estrutura de pedra sobre a qual é instalado um cruzeiro, localizado em frente à igreja. ${ }^{42}$

Os Carmelitas deixaram marcas do uso da iconografia tropical em duas igrejas. Em Mogi das Cruzes, a igreja da Ordem Terceira do Carmo, de 1762, apresenta, em um vestíbulo antecedendo a sacristia, o teto decorado com arranjos de flores pintados em tábuas (Figuras 16, 17 e 18).

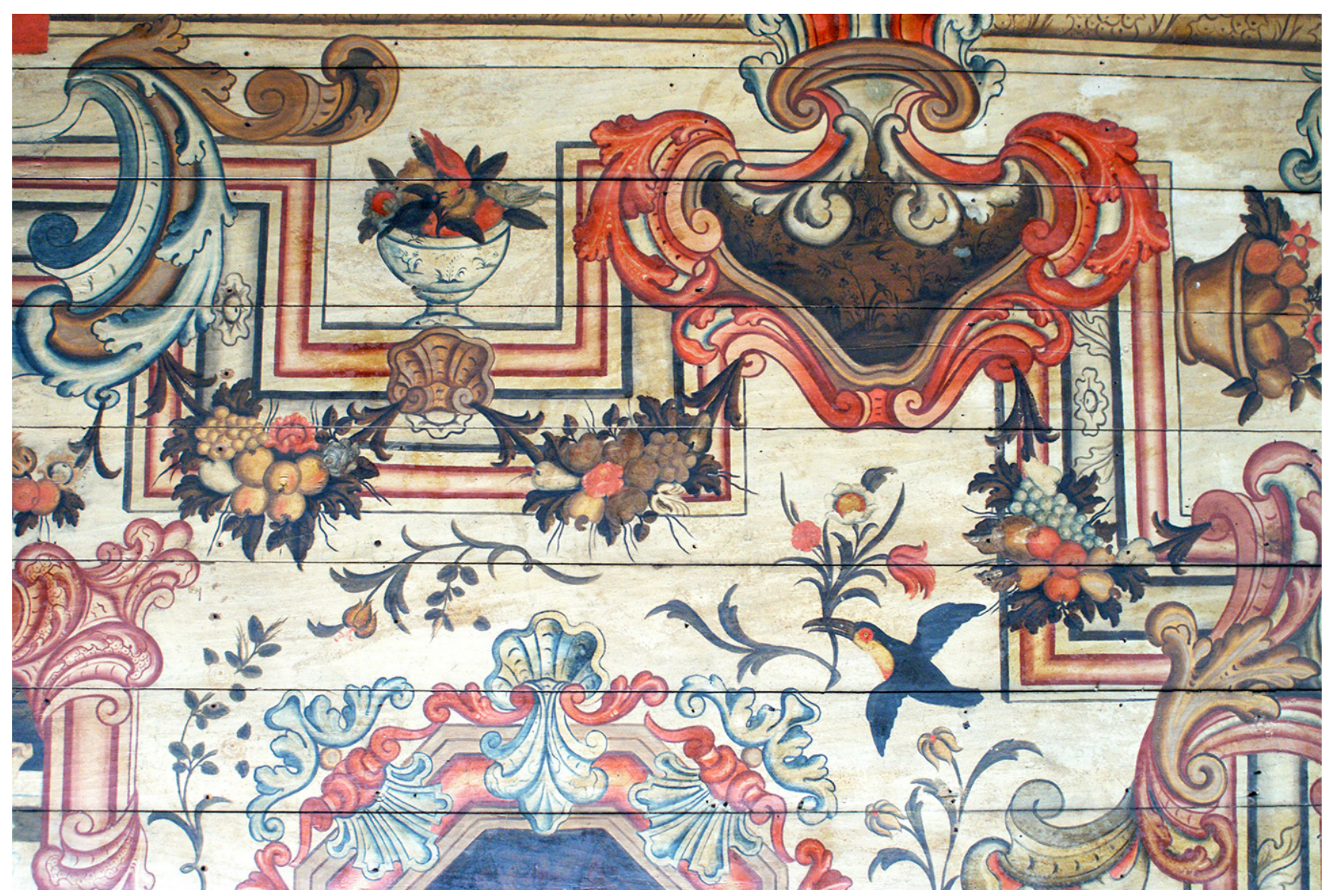

Figura 16 - Pintura do século XVIII em teto de vestíbulo da igreja da Ordem Terceira do Carmo, Mogi das Cruzes, SP, mostrando arranjos de frutas tropicais e pássaros brasileiros - tucano. Fotografia do autor

Segundo Tirapeli e Salomão:

Essa pintura foi trazida de outro local e comprovadamente adaptada, pois as pranchas precisaram ser cortadas nas pontas e acrescidas nas laterais, vendo-se que vieram de um ambiente mais comprido e estreito. Até o momento, não há informações sobre sua origem, nem mesmo se sabia que era exótica - o que é muito evidente para um restaurador. É uma pintura que segue a tradição dos tetos das sacristias, desde os brutescos ou ramículos das constru- 
ções jesuíticas até a observação aguda dos artistas franciscanos, que traziam os elementos vivos da natureza brasileira, como as pinturas do teto da sacristia do convento de Senhora das Neves, em Olinda. ${ }^{43}$
43. Tirapeli; Salomão, (2005, p. 114).

As pinturas no vestíbulo da sacristia de Mogi das Cruzes foram feitas por artistas da região do Serro e Diamantina. Não há data de sua execução, mas a pintura da nave tem autoria atribuída a Manoel do Sacramento, enquanto o teto da capela-mor teve a pintura executada em 1814-1815.
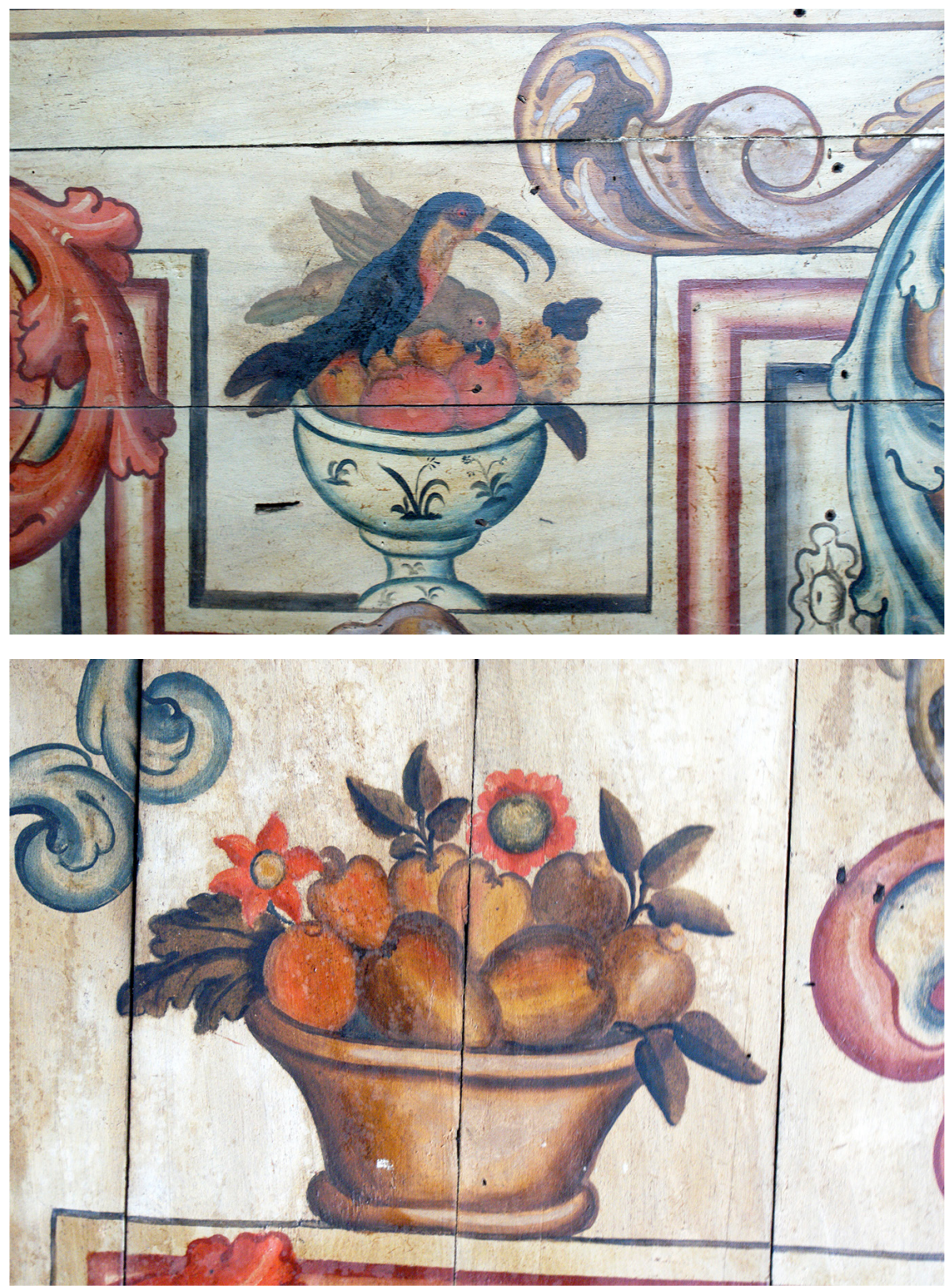

Figuras 17 (acima) e 18 - Detalhes de pintura do teto do vestíbulo da igreja da Ordem Terciária do Carmo, Mogi das Cruzes, mostrando arranjos de frutas e pássaros brasileiros. Fotografias do autor 

Lucena, na Paraíba, na igreja de Nossa Senhora da Guia. Nesse belo templo inacabado, construído em 1760, encontra-se um raro exemplo de uma fachada toda esculpida em pedra calcária, com festões de frutas sobrepostos emoldurando o nicho central. Entre as frutas, encontram-se abacaxis, cajus e frutos do cacau, além de outros não identificados.

Interpretando a iconografia tropical barroca

A ornamentação do frontispício da igreja de Nossa Senhora da Guia, em Lucena, completa nosso levantamento da presença das frutas tropicais na arte sacra colonial e revela a propagação desse tema em uma extensão do território que vai do nordeste ao sudeste, compreendendo ocorrências nos estados da Paraíba, Bahia, Pernambuco, e São Paulo. Como dito anteriormente, não foi encontrada nenhuma ocorrência no estado de Minas Gerais. No entanto, é preciso lembrar que a pintura do teto da igreja carmelita de Mogi das Cruzes é considerada por Tirapeli como produzida no norte de Minas Gerais, na região do Serro e Diamantina, feita para outro templo e adaptada, o que pode sugerir a presença desse repertório temático também na produção mineira. Como podemos ver na lista abaixo, os exemplos encontrados datam do período entre a segunda metade do século XVII e fins do século XVIII e disseminam-se entre as ordens jesuíta, franciscana e carmelita, as principais a atuarem no país durante o período colonial:

1 - Retábulo das Virgens Mártires e paredes do altar-mor da Basílica de Salvador, c. 1660-70. Jesuítas.

2 - Retábulo da capela de Nossa Senhora da Conceição, Voturuna, segunda metade do século XVII. Jesuítas.

3 - Pinturas no teto da sacristia da igreja conventual de Nossa Senhora das Neves, Olinda, início século XVIII. Franciscanos.

4 - Esculturas em pedra na fachada da igreja do convento de Santo Antônio do Paraguaçu, 1686. Franciscanos.

5 - Pinturas no teto da sacristia da igreja da Ordem Terceira do Carmo, Mogi das Cruzes, fins do século XVIII. Carmelitas.

6 - Esculturas em pedra na fachada da igreja de Nossa Senhora da Guia, em Lucena, 1760. Carmelitas.

Alguns autores apontam a origem dessa temática tropical na arte barroca brasileira como manifestação de um nativismo dos artesãos locais. Para o estudioso da cultura brasileira Roger Bastide,

[...] o barroco, quando chegou ao Brasil, foi transformado, nacionalizado, sobretudo pelas mãos de mestiços e mulatos, colocando negrinhos nas cortes dos anjos, fazendo eclodir cocares de plumas indígenas sobre as virgens dos capitéis, misturando os frutos da terra com o trigo e as uvas da eucaristia. ${ }^{44}$ 
Frederico Morais também defende essa posição. Para ele:

Esta presença maciça de uma mão-de-obra local la partir do século XVII totalmente indígena ou mestiça na América Central e nos Andes, negra e principalmente mulata no Brasil) na realização da arquitetura, da ornamentação interna e externa e, depois, na feitura de imagens e pinturas acabou por colorir com uma contribuição peculiar a arte que se fazia no continente. ${ }^{45}$

Morais sugere mesmo que tais manifestações de temas locais na arte colonial brasileira sejam interpretadas como um sinal de resistência cultural, reportando-se aos estudos de François Cali sobre a arte barroca latino-americana. Para Morais,

[...] como demonstrou François Cali, esta ornamentação foi o caminho encontrado pelas populações locais para se manifestarem no quadro de uma religião e de uma arquitetura impostas militarmente, mediante a introdução de símbolos da cultura autóctone e o uso de materiais locais, como a pedra sabão. ${ }^{46}$

É preciso ter em vista, no entanto, que a proposta de Cali, apresentada em The Art of the Conquistadors ${ }^{47}$, refere-se principalmente à arte barroca hispano-americana desenvolvida em regiões onde existiam, à época da chegada dos colonizadores europeus, civilizações de cultura material mais complexa que a encontrada no território brasileiro. Nesses locais, a simbologia religiosa católica deparou com uma rica iconografia nativa com a qual se associou, gerando uma iconografia híbrida. É o chamado barroco mestizo, no qual a longa tradição artística local se mesclou à arquitetura missionária, produzindo obras híbridas como a encontrada na porta da igreja de São Miguel, construída no início do século XVII em Pomata, Peru, onde se podem ver influências da arte précolombiana nos padrões geométricos tradicionais da arte andina, assim como na figura da sereia tocando charango, típico instrumento andino. $\bigcirc$ caráter anticolonial desse fenômeno, no entanto, deve ser relativizado, uma vez que tal hibridez pode ser interpretada tanto como uma atitude de resistência cultural dos artistas locais, quanto uma estratégia de assimilação dos símbolos indígenas no discurso católico com propósitos missionários.

No caso do Brasil, porém, os europeus depararam com diferentes etnias que viviam, de uma maneira geral, em sociedades descritas em 1576 por Pero de Magalhães Gândavo como "sem fé, nem lei, nem rei", 48 por não se organizarem sob uma religião ou governo aos moldes europeus ou mesmo aos encontrados nas civilizações andinas e da mesoamérica. Em que pese a visão eurocêntrica dos colonizadores demonstrada em tal assertiva, não havia, efetivamente, entre os indígenas brasileiros, uma cultura material desenvolvida (em termos de arquitetura, escultura e pintura) como a produzida pelos povos maias, incas e astecas, por exemplo, que tenha influenciado o barroco importado, pelo menos no que se refere ao aproveitamento visual das frutas nativas. A própria presença da mão de obra indígena na construção e decoração das
45. Morais (2001, p. 7).

46. Morais (2001, p. 7).

47. Cali (1961).

48. Gandavo (2008, p. 10). 
49. Costa (1941, p. 97).

50. Andrade (1969, p. 15).

51. Bazin (1956, p. 346). igrejas brasileiras é relativizada pelos estudiosos. Como sugere Lúcio Costa, ao tratar das especificidades do barroco brasileiro:

Provém, repito, talvez mais dessa mistura de procedências diversas combinadas com as deficiências do meio, que, propriamente, da influência do elemento nativo. Este, vencida a primeira fase de rebeldia, deixou-se moldar com docilidade pela mão poderosa do jesuíta. Parece mesmo não ter havido da parte dos irmãos, cientes da superioridade de sua própria técnica, compreensão e simpatia pelo que as interpretações dos indígenas pudessem apresentar de imprevisto e pessoal, e que desprezavam como 'errado' tudo que fugisse às receitas dos formulários europeus, estimulando, pelo contrário, as cópias servis e assim impondo, junto com a nova crença e a nova moral, uma beleza já pronta. ${ }^{49}$

\section{É a mesma posição de Rodrigo M. F. de Andrade:}

A mão de obra escrava do período do povoamento não imprimiu sinais de sua origem africana ou ameríndia nas produções de arquitetura, escultura e pintura aqui ocorridas, embora porventura as tivesse deixado em alguns utensílios e outros produtos de artesanato doméstico. $O$ poder de influência de suas aptidões artísticas congênitas veio a se verificar, entretanto, quando pelo efeito da miscigenação, os mestres mais inventivos e exímios, arquitetos, escultores, pintores e músicos, começaram a emergir das gerações de mestiços da população. ${ }^{50}$

Germain Bazin também trata da questão, apontando a exceção do Brasil em relação a outras ex-colônias latino-americanas:

No conjunto da arquitetura latino-americana, a escola brasileira é aquela que se encontra mais estreitamente associada às produções metropolitanas. Não se encontra no Brasil o fenômeno de indigenização que marca, por exemplo, o ultrabarroco mexicano ou boliviano, sem dúvida porque a reação do substrato não podia se manifestar nessas terras, onde os portugueses encontraram apenas povos selvagens, em um grau de civilização bem inferior [....$^{51}$

Apesar de sempre lembrada quando se trata de afirmar uma particularidade na arte barroca produzida no Brasil, a presença de uma temática local (no mais, limitada basicamente à representação das frutas tropicais, e ainda mais raramente, à figura do indígena, do negro e do mestiço) como um ato de resistência ou afirmação da cultura nativa não resiste a um exame mais atento das evidências. Segundo o ponto de vista aqui defendido, as representações de frutas e tipos locais responde muito mais a um olhar exótico do colonizador europeu sobre o território do que a uma autorrepresentação do nativo na arte aqui produzida. No caso específico das decorações com frutos, apontamos sua origem clássica, adaptada à realidade local como parte do processo de catequização e de interpretação da natureza do Novo Mundo promovido pelos missionários católicos.

Ainda que os exemplos aqui elencados da presença das frutas tropicais nas igrejas coloniais sejam poucos, sua propagação em uma grande extensão do território sugere que tais manifestações temáticas não surgiram como um fato 
isolado, relacionado à ação de algum artesão nativo que decidiu substituir as frutas 52. Cali (1961, p. 30). europeias pelas brasileiras por amor à terra natal ou por referência a uma tradição local em representá-las. Ao contrário, tais manifestações parecem ter sido disseminadas a partir das comunicações que as ordens religiosas que as encomendavam e produziam mantinham entre si. Ademais, a presença das frutas tropicais na ornamentação não é um fenômeno exclusivo do barroco brasileiro, ocorrendo também no barroco hispano-americano.

A ideia de que a inabilidade dos artesãos locais os fizessem voltar-se para a representação dos frutos tropicais em substituição aos europeus por sua maior intimidade com as formas nativas e uma maior facilidade em esculpi-las ou pintá-las também parece não proceder. Além de os artesãos trabalharem sob a supervisão dos padres e missionários, não raramente fazendo parte de seu corpo, que impunham modelos a serem seguidos, não havia à época o costume de se pintar ou modelar a partir da natureza. Os artistas se inspiravam em outras obras e em reproduções para criarem, de forma que seria mais fácil para um artista inábil copiar uma maçã ou cacho de uva encontrada em algum trabalho europeu do que representar uma fruta nativa. É bom lembrar que os indígenas brasileiros, apesar de possuírem uma rica cultura artística - que vai da arte plumária, passando pela pintura corporal e pela cerâmica marajoara, para citar apenas alguns exemplos - não possuíam uma tradição de representação visual mimética da flora brasileira que pudesse alimentar essa presença da flora local na arte barroca.

Se como tema a própria imagem do indígena aparece como uma rara exceção na ornamentação das igrejas barrocas brasileiras, a presença de uma influência do repertório ornamental das culturas indígenas na decoração das igrejas coloniais torna-se praticamente invisível. A avaliação que François Cali faz do barroco mestizo, alimentado pela tradição indígena, não pode, portanto, ser aplicada ao caso brasileiro. Segundo Cali:

\footnotetext{
A arquitetura nas colônias latinas estava raramente nas mãos de índios ou mestiços. $\bigcirc$ projeto de uma igreja poderia ser chamado uma questão de dogma, a preocupação de teólogos que eram certamente europeus, enquanto sua ornamentação era uma liturgia, aberta a tantas interpretações quanto havia de nações. A originalidade nativa, peruana ou mexicana, é aparente apenas em temas menores, pertencendo à ornamentação e isso com certeza explica sua proliferação única no barroco colonial. Apenas aqui era o nativo capaz de dar asas às suas ideias decorativas, passadas pelos oleiros e tecelões através de longos séculos antes da chegada de Colombo. Neste domínio ele iria reconquistar a arte imposta sobre ele, usando especialmente seus padrões geométricos. ${ }^{52}$
}

mesmo tipo de liberdade criativa na ornamentação sacra colonial parece não ter sido compartilhado pelo barroco brasileiro. Talvez, nas missões jesuíticas fundadas no sul do país, os chamados Sete Povos das Missões, essa marca indígena pudesse se apresentar de forma mais patente na arte e arquitetura ali desenvolvidas. No resto do país, especialmente em Minas Gerais e na Bahia, 
53. Filho (2015, p. 164)

54. Costa (1941, p. 29, 54).

55. Meyer (1957).

56. Costa (2005, p. 62). coube ao negro, ou ao mulato, uma contribuição mais reconhecida para o abrasileiramento do barroco.

Todos esses fatores nos levam a desconsiderar a participação do elemento indígena na criação e disseminação das representações das frutas locais no barroco brasileiro, como alguns autores sugerem. Egydio Colombo Filho, por exemplo, a respeito do retábulo de Voturuna, já apresentado, avalia:

Seu altar mostra a influência do mameluco e do indígena, alheios estes aos princípios artísticos europeus da época. Tem concepção sóbria e combina temas populares, como pencas de frutas, reunindo temas eruditos em talha com execução de modo naturalista; recria, assim, as formas de manifestação religiosa e patenteia uma espécie de hibridismo estilístico. ${ }^{53}$

Segundo nosso ponto de vista, a execução deste altar pode ter origem indígena, mas os elementos ornamentais são copiados de modelos europeus, de forma que as pencas de frutas que nele figuram não podem ser vistas como temas populares, uma vez que têm uma origem clássica e renascentista. Ao considerá-lo "uma versão popular dos nobilíssimos retábulos jesuíticos do primeiro período", Lucio Costa ressalta a obediência aos modelos europeus, inclusive nas pencas de frutas, que reconhece serem: "as frutas amarradas por uma faixa-motivo europeu então na moda e já encontrado no frontão do retábulo da igreja de São Lourenço dos Índios [...]". ${ }^{54}$

Além de não haver uma tradição indígena na representação visual das frutas tropicais, o tema da representação de frutas na ornamentação arquitetônica já fazia parte de uma longa tradição europeia que foi exportada para a América, tendo sido apenas adaptada à realidade local. $\bigcirc$ uso de frutas como ornamento na arquitetura ocidental remonta ao período clássico. Segundo Franz Sales Meyer,

[...] a origem desse estilo de decoração deve ser procurada na circunstância em que festões de frutas reais eram penduradas nos frisos dos templos, alternando com caveiras reais de animais sacrificiais abatidos...Esse estilo de decoração foi transferido da arquitetura sagrada para a secular, revivido pelo Renascimento em formas mais ou menos alteradas $[\ldots] .{ }^{55}$

Já no período clássico, as frutas eram usadas como ornamento em diferentes formas: em arranjos nos frisos iônicos e coríntios, em cestas, festões, cachos e cornucópias, muitas vezes junto a flores. Como afirma Mozart Bonazzi da Costa,

[...] todas as classes de ornatos encontráveis nos templos da Antiguidade clássica, executados originalmente em pedra, podem ser encontrados, reproduzidos ou representados, em pintura, desenho, gravura e escultura e nas artes aplicadas renascentistas. ${ }^{56}$

Boa parte do repertório ornamental católico do barroco europeu, portanto, tem origem clássica, recuperado pelo Renascimento, como as folhas de acanto, as pinhas, os arranjos de frutas e outros. Esse repertório chegou ao Brasil 
no período do maneirismo e, de uma forma geral, irá prevalecer até o período do rococó, com suas devidas variações.

Pode-se afirmar que o repertório temático e simbólico da ornamentação barroca brasileira é todo de origem europeia, com exceção das frutas tropicais, que, na verdade, não passam de uma variação de um tema clássico, como já apontamos. E elas vão ser representadas nas igrejas brasileiras em todas as formas que citamos: em festões, como os esculpidos na fachada da igreja de Nossa Senhora da Guia, em Lucena, PB, e os pintados no teto da igreja da ordem Terceira do Carmo, em Mogi das Cruzes, SP; em cachos, como os presentes na fachada da igreja de Santo Antonio do Paraguaçu, em Cachoeira, BA, e no retábulo de Voturuna, em São Paulo; e em cestas, como as vistas nas pinturas da sacristia da igreja de Nossa Senhora das Neves, em Olinda, PE, e também no teto da citada igreja carmelita de Mogi das Cruzes.

Se o motivo das frutas como ornamento já era um tema clássico, tampouco sua versão em frutas nativas parece originar-se de uma interpretação popular, cuja tradição não existia, como já abordamos. Antônio José Góis, em seu estudo sobre os retábulos no barroco luso-brasileiro, avalia a presença dos elementos da natureza local na arte jesuíta como parte da estratégia missionária. Segundo Góis, ao tratar do retábulo das Virgens Mártires da Basílica de Salvador:

[...] os painéis desta divisão inferior do retábulo obedecem à concepção naturalística que parece refletir intenção inédita de traduzir o ambiente da terra com os meios expressivos oriundos da tratadística do Maneirismo, que incluem o elemento zoo-antropomorfo. Lembremos que na época o Colégio ainda se constituía o centro logístico das missões no interior, podendo-se estabelecer a hipótese de uma referência à catequese pelo artífice. ${ }^{57}$

Ao ressaltar o poder que a arte religiosa barroca operava na integração dos povos colonizados à civilização europeia, Góis reconhece que "teria sido um traço peculiar do estilo o amoldar-se a diferentes regiões e culturas fornecendo-lhes a expressão local, não raro de raiz autóctone, como sucedeu no mundo hispânico". Ao mesmo tempo, o autor relaciona as frutas tropicais ao imaginário do paraíso na América, defendido pelo jesuíta Simão de Vasconcelos:

Nesse espírito do escritor jesuíta se traduz a primeira manifestação de ufanismo, o qual encontra uma evidente confirmação na transposição dos motivos fitomorfos - que, das frutas europeias utilizadas em época renascentista, conforme uma tradição bem exemplificada pelo lavabo da sacristia da Santa Casa de Misericórdia, tornam-se frutas tropicais condizentes com o novo ambiente. Assinala-se, assim, a primeira tomada de consciência pelo artista europeu do meio em que havia se fixado, com reflexos imediatos em artistas de diferentes regiões. ${ }^{58}$

A conversão das frutas europeias em brasileiras não partiu do olhar ingênuo e nativista de um artista local destreinado, mas de uma leitura teológicocristã dos missionários que identificavam o Novo Mundo com o paraíso terreal. É dentro dessa perspectiva que o aproveitamento das frutas tropicais pelo barroco 
59. Costa (2005, p. 62).

60. Cirlot (2002, p. 3).

61. Cooper (2012).

62. Costa (2005, p. 64). brasileiro deve ser visto, como parte da visão de mundo representada pelo pensamento cristão e como uma estratégia de aproximação dos missionários com a realidade local. A apropriação pela lgreja católica de símbolos e iconografia de outras culturas e religiões é uma estratégia desenvolvida ao longo de sua história, e o próprio aproveitamento dos motivos clássicos gregos pagãos aponta nessa direção. Ao incorporar muitos desses motivos clássicos, a lgreja católica lhes atribuiu novos significados, à luz da teologia cristã. Como afirma Bonazzi da Costa, a riqueza do discurso iconográfico da arte sacra barroca deve-se "à inteligente escolha de alguns dos mais significativos entre os elementos iconográficos da tradição católica e pagã pela cúpula eclesiástica da lgreja de Roma" [na decoração de suas igrejas]. ${ }^{59}$ Entre alguns desses elementos que receberam novos significados, podemos destacar as folhas de acanto, os arranjos de flores e frutas, as pinhas e a videira.

As folhas de acanto, por exemplo, um motivo clássico presente nos capitéis da ordem coríntia, recebeu na ldade Média um significado cristão "derivado de suas duas características principais: seu crescimento e seus espinhos. $\bigcirc$ último é um símbolo da solicitude para com as coisas humildes. De acordo com o bispo Melito de Sardis, eles significam a consciência e a dor do pecado". 60 A mitológica ave fênix, símbolo da imortalidade desde os tempos antigos, tornou-se símbolo da ressurreição de Cristo. A videira e os cachos de uvas, que, na Grécia antiga, eram associados a Dionísio e em Roma a Baco, tornaram-se símbolos do sangue de Cristo. A fruta romã, originária da Pérsia, na antiguidade era associada à fertilidade, sendo atributo das deusas Hera e Afrodite. No catolicismo, a romã passou a ser símbolo da perfeição divina e da virgindade de Maria. ${ }^{61}$ A maçã, símbolo do amor na mitologia grega, tornou-se símbolo do pecado e da tentação na fé católica. Outros símbolos tradicionais encontrados na ornamentação cristã são: as espigas, sinais de fartura; flores, como sinal de esperança. Como descreve Bonazzi da Costa, "entre as flores, os jacintos serão marcas da sabedoria; os narcisos, da gentileza; o lírio, de pureza. Entre as frutas, a maçã terá o significado da discórdia; o pêssego, de intimidade; e a pera, de perfeição". ${ }^{62}$

Todo esse arsenal simbólico era utilizado no processo de catequese, que envolvia também a construção e ornamentação das igrejas com as imagens cristãs. Porém, apesar de as frutas tropicais se inserirem nesse arsenal simbólico, sua incorporação não partiu da existência de alguma tradição simbólica autóctone aproveitada pelos missionários, mas foi de inspiração totalmente erudita e europeia. Da mesma maneira que a tradição cristã se apropriou de símbolos pagãos, as frutas tropicais também foram apropriadas simbolicamente. Se, em relação aos símbolos pagãos, foi necessário adaptar ou substituir seus significados tradicionais pelos cristãos, no caso da natureza brasileira e, mais especificamente, das frutas tropicais, foi preciso inventá-los, pois não havia uma interpretação prévia para eles, seja nas culturas antigas (que os desconheciam) ou mesmo nas aqui encontradas. 
Essa interpretação da natureza do Novo Mundo, no entanto, não se dava apenas como um processo de aproximação da realidade dos habitantes locais, mas estava incorporada na visão de mundo informada pelo pensamento teológico cristão que perdurou até os fins do século XVIII no mundo ocidental. Para Holanda, essa visão teológica conduziu o olhar dos colonizadores sobre a natureza do Novo Mundo. Segundo o autor,

[...] não admira, nessas condições, que vicejasse facilmente, entre eles, um modo aparente de ver a natureza, que consiste antes em ver através e apesar da natureza. $\bigcirc$ mundo empírico só vale na medida em que nos descobre os degraus necessários para ascendermos, dentro dos limites humanos, até o conhecimento das coisas invisíveis e espirituais. ${ }^{63}$

À visão, nesse sentido, é dada a primazia sobre os outros sentidos, por dar acesso ao mundo corpóreo, tanto celeste como inferior. Assim, "é na importância desse pregar aos olhos que vão ganhar seu maior valor as 'prédicas' e 'sermões' da natureza". A pregação, portanto, servia-se de imagens autênticas ao citar os elementos da natureza:

[...] compostas pela mão de Deus, hão de ter, talvez, mais eficácia do que as figuras fabricadas pela arte e pelo engenho dos homens como testemunho dos sagrados mistérios, de sorte que a figura e a semelhança das coisas sensíveis venham a dar um antegozo das espirituais e eternas. ${ }^{64}$

E a flora brasileira oferecia essas imagens. Assim, a incorporação das frutas no visual barroco das igrejas brasileiras não apenas sugeria uma aproximação com a realidade local, mas oferecia a possibilidade de sua interpretação enquanto símbolos da universalidade e da presença cristã no Novo Mundo. A produção artística e iconográfica do período barroco deveria, portanto, integrar-se no discurso religioso católico, obedecendo a essa hierarquização simbólica. Como coloca João Adolfo Hansen,

[...] as artes [nesse período] têm uma fundamentação metafísica, substancialista, e não conhecem a autonomia estética que passaram a ter depois do século XVIII, pois todas elas são então entendidas como dispositivos imediatamente práticos, úteis, que dramatizam espetacularmente os valores católicos da monarquia absolutista. ${ }^{65}$

Para Hansen, as artes são propostas no período entre 1580 e 1750 como Theatrum Sacrum. Pela noção de teatro, pensa-se numa atividade de encenação de certos preceitos e princípios básicos da doutrina cristã. Por sacro, entendem-se duas coisas:

[...] a primeira, que a referência principal de toda representação é a história sacra, tal como exposta na Bíblia ou nos comentários dos doutores da lgreja; a segunda é que os significados e os sentidos dados em representação são sagrados, pois evidenciam a presença da luz divina $[\ldots] .{ }^{66}$ 
67. Hansen (2005, p. 183).

68. Bazin (1956, p. II-III).

69. Bazin (1956, p. II-III).

70. Bastide (2011, p. 50).
O encontro com a natureza americana, nunca antes descrita ou representada, seja nos textos sagrados ou pagãos, ofereceu um novo arsenal de imagens a serem "decifradas" (o que significava interpretá-las segundo o pensamento cristão) e apropriadas. E essa apropriação dava-se pela alegorização:

[...] por definição, como a mente humana é finita, ou seja, incapaz de conceber Deus sem imagens, todo conhecimento humano é indireto, ou teórico ou analógico, feito sempre mediante representações ou imagens dos conceitos, ou seja, por meio de metáforas. ${ }^{67}$

Germain Bazin, em seu clássico L'architecture religieuse au Brésil (1956), comenta sobre a presença da alegoria na arte barroca e jesuítica:

Esse gosto pela alegoria [que] no século XVII torna-se uma verdadeira mania do humanista, no qual se deleitavam notadamente os jesuítas; eles se mostraram virtuoses na arte de colocar em emblemas e em imagens todas as noções do universo, sagrado ou profano. ${ }^{68}$

Como continua Bazin, aos olhos dos homens dessa época, "a ficção aparece como o signo sob o qual se manifesta uma realidade escondida, contendo uma verdade moral que não é susceptível de reprodução, mas que é transferida em um jogo de aparências". 69

A associação mais óbvia que os portugueses fizeram da natureza brasileira foi com o paraíso terreal, abraçada pelos cronistas da época e defendida mais veementemente pelo jesuíta Simão de Vasconcelos, como bem analisou Sérgio Buarque de Holanda em Visão do Paraíso. Esse processo de apropriação discursiva e alegórica da natureza brasileira se iniciou nos séculos XVI e XVII, nos relatos dos viajantes portugueses, e culminou na obra de Frei Antônio do Rosário, Frutas do Brasil, publicada em 1702 em Lisboa, como mostramos. A presença das frutas tropicais na ornamentação barroca colonial brasileira, portanto, teria partido muito mais de um olhar exótico e colonialista do missionário europeu sobre a natureza do Novo Mundo, informado pela teologia cristã e pelo modo alegórico de interpretar a realidade, do que de um nativismo, indígena ou mestiço, embrião de um discurso nacionalista. Com isso, queremos dizer que ainda que se possa reconhecer essa temática como parte dos fundamentos de um caráter original na arte aqui produzida durante o período colonial, sua origem é exógena, tendo sido posteriormente aproveitada pelo discurso nacionalista que se construiv ao longo de nossa história, especialmente no século XIX.

Como tão bem colocou a questão, o estudioso da cultura brasileira Roger Bastide sustenta que:

É preciso lembrar que pintar a natureza brasileira no que ela tem de mais tropical, de mais antieuropeu, é de um nativismo ilógico. Porque, quer queira quer não, o artista se coloca, para isso, exatamente no mesmo pé que o estrangeiro recém-chegado: quer dar uma sensação de exotismo. Para poder elogiar o que a paisagem carioca [ou brasileira] tem de original, é preciso compará-la mentalmente com outras, e, logo, adotar, provisoriamente pelo menos, uma alma europeia. ${ }^{70}$ 
Tais razões nos levaram a considerar as origens eruditas da ornamentação com frutas tropicais no barroco brasileiro e a vê-la não como um ato de resistência ou de adaptação dos modelos europeus pelo artesão nativo, mas como parte de um processo de interpretação e posse da natureza americana pela religião católica. Ademais, considera-se que esse sistema imagético foi usado como estratégia no processo missionário, caracterizando uma situação persistente na história cultural brasileira: uma cultura que se olha (e se representa) na imagem refletida pelo espelho europeu, frequentemente emoldurado pelo exotismo.

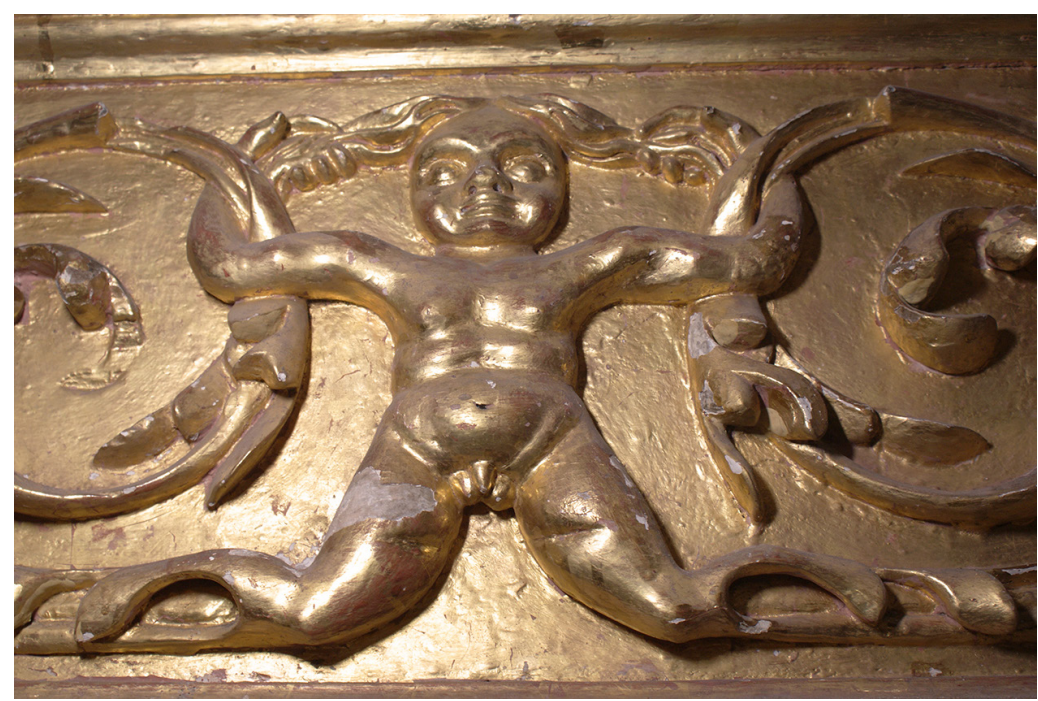

Figura 19 - Detalhe decorativo de lateral do altar-mor da Basílica de Salvador. Fotografia do autor. 


\section{REFERÊNCIAS}

\section{ARTIGOS, LIVROS E TESES}

ANDRADE, Rodrigo Melo Franco de. Palestra. Revista do Patrimônio Histórico e Nacional, Rio de Janeiro, n. 17, p. 11-26, 1969.

BASTIDE, Roger. Impressões do Brasil. São Paulo: Imprensa Oficial, 2011.

BAZIN, Germain. L'Architecture Religieuse Baroque au Brésil. SP: Museu de Arte; Paris: Librairie Plon, 1956.

BIANCARDI, Cleide Santos Costa. Liturgia, arte e beleza: o patrimônio móvel das sacristias barrocas no Brasil. In: TIRAPELI, Percival (Org.). Arte sacra colonial. SP: Imprensa Oficial de SP, 2005. p. 42-57.

BIRON, Berty Ruth Rothstein. Frutas do Brasil: uma alegoria do Novo Mundo. Revista do Núcleo de Estudos de Literatura Portuguesa e Africana da UFF, v. 2, n. 3, p. 47-57, nov. 2009. Disponível em <http://www.revistaabril.uff.br/index.php/ revistaabril/article/view/241> Acesso em: 24 abr. 2013.

CALI, François. The art of the conquistadors. London: Thames and Hudson, 1961.

CAMINHA, Pero Vaz de. A Carta. Rio de Janeiro: Biblioteca Nacional, 2013. Disponível em: < http://www.dominiopublico.gov.br/download/texto/ua000283.pdf>. Acesso em: 14 fev. 2016.

CARDIM, Fernão. Tratado da terra e da gente do Brasil. São Paulo: Cia. Editora Nacional, 1939.

CIRLOT, Juan Eduardo. A dictionary of symbols. Trad. Jack Sage. New York: Dover Publications, 2002. Livro eletrônico.

COLOMBO FILHO, Egydio. Sobre os objetos barrocos. In: TIRAPELI, Percival. (Org.). Arte sacra colonial. São Paulo: Imprensa Oficial-UNESP, 2005. p. 146-165.

COOPER, Jean Campbell. An illustrated encyclopaedia of traditional symbols. London: Thames and Hudson, 2012. Livro eletrônico.

COSTA, Lúcio. A arquitetura dos jesuítas no Brasil. Revista do Serviço do Patrimônio Histórico e Artístico Nacional. Rio de Janeiro, n. 5, p. 9-104, 1941. 
COSTA, Mozart Alberto Bonazzi da. A talha dourada na antiga província de São Paulo: exemplos de ornamentação barroca e rococó. TIRAPELI, Percival. (Org.). Arte sacra colonial. São Paulo: Imprensa Oficial-UNESP, 2005. p. 60-81.

FLEXOR, Maria Helena Ochi. Igrejas e conventos da Babia. Brasília: Iphan, 2010.

GANDAVO, Pêro de Magalhães. Tratado da Terra do Brasil. História da Província Santa Cruz, a que vulgarmente chamamos de Santa Cruz (1576). Brasília: Senado Federal, 2008. Disponível em: <<http://www2.senado.leg.br/bdsf/bitstream/handle/id/ 188899/ Tratado \%20da \%20 terra\% 20do\%20 Brasil.pdf?sequence=1>>. Acesso em: 27 Abril 2015.

GÓIS, Antônio José Sapucaia de Faria. Fatores condicionantes na morfologia do retábulo. 2005. 351 p. Tese (Doutorado em Arquitetura). Faculdade de Arquitetura e Urbanismo, USP, São Paulo, 2005. Disponível em: <<http://www2.cm-evora.pt/retabulosdeevora/ bibliografia/ 2\%20fatores \%20condicionantes.pdf $>$. Acesso em: 10 jun. 2014.

Interpretando a talha barroca. Repertório: teatro e dança. Ano 13, n. 14, p. 49-55, 2010. Disponível em: < http://www.portalseer.ufba.br/index.php /revteatro/article/view/4664> Acesso em: 11 jul. 2014.

GÓMEZ, Francisco Javier Pizarro. Identidad e mestizaje en el arte barroco andino. La iconografia. MARTINS, Fausto Sanches (Coord.). In: CONGRESSO INTERNACIONAL DO BARROCO, II, Porto. Anais eletrônicos... Porto: FLUP, 2003, p. 197-213. Disponível em: < http://ler.letras.up.pt/uploads/ficheiros/7511.pdf>. Acesso em: 03 jul. 2015.

HANSEN, João Adolfo. Artes seiscentistas e teologia política. TIRAPELI, Percival. (Org.). Arte sacra colonial. São Paulo: Imprensa Oficial-UNESP, 2005. p. 180-189.

HATHERly, Ana. Antônio do Rosário: Apresentação. In: ROSÁRIO, Antônio do. Frutas do Brasil: numa nova, e ascética Monarchia, consagrada à Santíssima Senhora do Rosário. Fac-símile da edição de Lisboa: António Pedroso Galvão, 1702. Lisboa: Biblioteca Nacional, 2002. p. 9-25.

HOLANDA, Sérgio Buarque de. Capítulos de literatura colonial. São Paulo: Brasiliense, 1991. . Visão do paraíso. Os motivos edênicos no descobrimento e colonização do Brasil. São Paulo: Publifolha, 2000.

ITAPARICA, Frei Manuel de Santa Maria. Descrição da Ilha da Maré. In: Eustáquidos. Disponível em: < http://www.literaturabrasileira. ufsc.br/ documentos/?action= download\&id = 28092> . Acesso em 22 nov. 2013. 
KOCH, Gloria. A presença indígena nas capelas da capitania de São Vicente (século XVII). Espaço Ameríndio. Porto Alegre, v. 5, n. 2, p. 45-73, out. 2011.

LÉRY, Jean de. Viagem à terra do Brasil. Trad. Sérgio Milliet. São Paulo: Martins-EDUSP, 1972.

LOTH, Calder. "Classical comments: The corinthian of the temple of Vesta at Tivoli". The Classicist Blog. Institute of Classical Architecture and Art, October 31, 2013. Disponível em < http://blog.classicist.org/?p=6922>. Acesso em: 01 jul. 2015.

MEYER, Franz Sales. Handbook of ornament. Dover pictorial archive. New York: Dover, 1957. Livro eletrônico.

MORAIS, Frederico et al. O Brasil na visão do artista. A natureza e as artes plásticas. São Paulo: Prêmio Editorial, 2001.

Pintura colonial. Cadernos de bistória da pintura no Brasil. São Paulo: Instituto Cultural Itaú, 1994.

OLIVEIRA, Manuel Botelho de. "À Ilha de Maré termo desta cidade de Bahia”. In: Música do Parnaso. Rio de Janeiro: Fundação Biblioteca Nacional, 2013. Disponível em: < http://www. dominiopublico.gov. br/ pesquisa/ DetalheObraForm. do?select_action=\&co_obra $=2094>$. Acesso em: 22 nov. 2013.

ROSÁRIO, Frei Antônio do. Frutas do Brasil: numa nova, e ascética Monarchia consagrada à Santíssima Senhora do Rosário. Fac-símile da edição de 1702. Rio de Janeiro: Fundação Biblioteca Nacional, 2008.

SALVADOR, Frei Vicente. História do Brasil. 1500-1627. ABREU, Capistrano de (Ed.). São Paulo: Weisflog Irmãos, 1918. Disponível em: < http://www.brasiliana.usp.br/ bbd/handle/ 1918/01861600\#page/21/mode/1up>. Acesso em: 28 abr. 2015.

SILVA, Antônio Manoel dos Santos. Literatura barroca e categorias não-literárias. TIRAPELI, Percival (Org.). Arte sacra colonial. São Paulo: Imprensa Oficial-UNESP, 2005. p. 210-27.

SMITH, Robert Chester. The Brazilian Landscapes of Frans Post. The Art Quarterly, Herbstt, 1, n. 4, 1938.

Arquitetura civil do período colonial. Revista do Patrimônio Histórico e Nacional, n. 17 , p. $27-127,1969$.

SOUSA, Gabriel Soares. Tratado descritivo do Brasil em 1587. VARNHAGEM, Francisco Adolfo (Ed.). Rio de Janeiro: Cia. Editora Nacional, 1938. Disponível em: <<http://www.brasiliana.com. br/obras/tratado-descritivo-do-brasil-em-1587/preambulo/8/ texto > . Acesso em 20 abril 2015. 
THEVET, André. Singularidades da França Antártica, a que outros chamam América. Trad. Estevão Pinto. São Paulo: Nacional, 1944.

TIRAPELI, Percival. Igrejas paulistas: Barroco e Rococó. São Paulo: Imprensa OficialUNESP, 2003.

. (Org.). Arte sacra colonial. São Paulo: Imprensa Oficial-UNESP, 2005.

Igrejas barrocas do Brasil. São Paulo: Metalivros, 2008.

SALOMÃO, Myriam. "Pintura colonial paulista'. In: TIRAPELI, Percival (Org.). Arte sacra colonial. São Paulo: Imprensa Oficial-UNESP, 2005. p. 90-117.

TOLEDO, Benedito Lima. Esplendor do barroco luso-brasileiro. Cotia: Ateliê Editorial, 2012.

VASCONCELOS, Simão de. Notícias curiosas e necessárias das cousas do Brasil. Lisboa: Oficina João da Costa, 1668. Disponível em: < http:// www.bibliotecadigital.unicamp.br/ document/?code= 000425958>. Acesso em: 20 ab. 2015.

Artigo apresentado em 17/05/2016. Aprovado em 19/08/2016. 